\title{
First insights into past biodiversity of giraffes based on mitochondrial sequences from museum specimens
}

\author{
Alice PETZOLD ${ }^{1}$, Anne-Sophie MAGNANT ${ }^{2}$, David EDDERAI ${ }^{3}$, \\ Bertrand CHARDONNET ${ }^{4}$, Jacques RIGOULET ${ }^{5}$, Michel SAINT-JALME ${ }^{6} \&$ \\ Alexandre HASSANIN ${ }^{7, *}$ \\ ${ }^{1,2,7}$ Institut de Systématique, Évolution, Biodiversité (ISYEB), Sorbonne Université, \\ MNHN, CNRS, EPHE, UA, Muséum national d'histoire naturelle, \\ 55 rue Buffon - CP 51 - 75005 Paris, France. \\ ${ }^{3} 5$ chemin du bas d'Anville - 17750 Etaules, France. \\ ${ }^{4} 92210$ Saint Cloud, France. \\ ${ }^{5}$ Deceased [18 May 2020]. Former address: Direction Générale Déléguée aux Musées, \\ Jardins Botaniques et Zoologiques, Muséum national d'histoire naturelle, \\ 57 rue Cuvier - 75005 Paris, France. \\ ${ }^{6}$ Centre d'Ecologie et des Sciences de la Conservation, UMR 7204 MNHN CNRS-UPMC, \\ Muséum national d'histoire naturelle - 75005 Paris, France. \\ *Corresponding author: alexandre.hassanin@mnhn.fr \\ 1Email: alice.petzold1@mnhn.fr \\ ${ }^{2}$ Email: annesophie.magnant@gmail.com \\ 32Email: davidedderai@hotmail.fr \\ ${ }^{4}$ Email: bertrand.chardonnet@gmail.com \\ ${ }^{6}$ Email: michel.saint-jalme@mnhn.fr

\footnotetext{
${ }^{1}$ urn:Isid:zoobank.org:author:E7FDAE2B-14A3-4B47-BD66-4E607AC5CEFB

${ }^{2}$ urn:1sid:zoobank.org:author:C202CFC1-8E73-460D-B0B8-6B00964CF40B

${ }^{3}$ urn:1sid:zoobank.org:author:5EDAF19C-7E3E-44DE-B5DE-510B60FD81C7

${ }^{4}$ urn:lsid:zoobank.org:author:3E4DC1DB-5AF4-4574-A14C-5A19BB78E231

${ }^{5}$ urn:lsid:zoobank.org:author:EC4BDEB1-B643-4D46-A960-D0BC44D0D9B3

${ }^{6}$ urn:Isid:zoobank.org:author:7754B40E-DEB5-4133-B91E-0C0341D2211D

${ }^{7}$ urn:1sid:zoobank.org:author:0DCC3E08-B2BA-4A2C-ADA5-1A256F24DAA1
}

This paper is dedicated to the memory of our colleague and friend, Dr. med.vet. Jacques Rigoulet, who passed away on 18 May 2020.

Abstract. Intensified exploration of sub-Saharan Africa during the $18^{\text {th }}$ and $19^{\text {th }}$ centuries led to many newly described giraffe subspecies. Several populations described at that time are now extinct, which is problematic for a full understanding of giraffe taxonomy. In this study, we provide mitochondrial sequences for 41 giraffes, including 19 museum specimens of high importance to resolve giraffe taxonomy, such as Zarafa from Sennar and two giraffes from Abyssinia (subspecies camelopardalis), three of the first southern individuals collected by Levaillant and Delalande (subspecies capensis), 
topotypes of the former subspecies congoensis and cottoni, and giraffes from an extinct population in Senegal. Our phylogeographic analysis shows that no representative of the nominate subspecies camelopardalis was included in previous molecular studies, as Zarafa and two other specimens assigned to this taxon are characterized by a divergent haplogroup, that the former subspecies congoensis and cottoni should be treated as synonyms of antiquorum, and that the subspecies angolensis and capensis should be synonymized with giraffa, whereas the subspecies wardi should be rehabilitated. In addition, we found evidence for the existence of a previously unknown subspecies from Senegal (newly described in this study), which is now extinct. Based on these results, we propose a new classification of giraffes recognizing three species and 10 subspecies. According to our molecular dating estimates, the divergence among these taxa has been promoted by Pleistocene climatic changes resulting in either savannah expansion or the development of hydrographical networks (Zambezi, Nile, Lake Chad, Lake Victoria).

Keywords. Giraffa, ancient DNA, Zarafa, conservation genetics, Pleistocene.

Petzold A., Magnant A.-S., Edderai D., Chardonnet B., Rigoulet J., Saint-Jalme M. \& Hassanin A. 2020. First insights into past biodiversity of giraffes based on mitochondrial sequences from museum specimens. European Journal of Taxonomy 703: 1-33. https://doi.org/10.5852/ejt.2020.703

\section{Introduction}

The Europeans saw for the first time a living giraffe in Roman times when Julius Caesar returned with a menagerie of exotic animals from Africa in $46 \mathrm{BC}$. The Romans named this extraordinary animal 'Cameleopard', due to its head and tail like a camel and coat like a leopard (Pliny the Elder AD 64 translated by Bostock \& Riley 1855). Based on the illustration of a living giraffe made by Belon du Mans (1553) and descriptions provided by subsequent authors (Ray 1653; Hasselquist 1757), Linnaeus (1758) classified the giraffe as Cervus camelopardalis Linnaeus, 1758 (type locality: Sennar and Ethiopia), because its horns were supposed to be similar to deer antlers. A few years later, Brisson (1762) emphasised the permanence of the horns and assigned giraffes to their own genus Giraffa Brisson, 1762. However, neither Brisson nor Linnaeus had ever seen a living giraffe.

During the years 1780-1785, the French explorer François Levaillant undertook two expeditions in the Cape of Good Hope (western part of present South Africa). During his second journey (1783-1785), he encountered several giraffes close to the Orange River (Levaillant 1797), of which he sent a skin to the Muséum national d'histoire naturelle (MNHN) in Paris (illustrated by von Schreber 1784) and a skeleton to the collection of the governor of Netherlands, Guillaume V, in The Hague, which was transferred to the MNHN in 1795 (Schickh 1828). Pierre-Antoine Delalande (1822) enriched the giraffe collection of the MNHN with three additional skulls and a skin from giraffes of the Cape Colony.

In 1824, two young giraffes were caught "eight to ten days' caravan south of Sennaar" (Salze 1827), the former capital of the Sennar region located in present Sudan. The giraffes were offered by Mehmet Ali, the Pasha of Egypt, to Charles X, King of France, and George IV, King of the United Kingdom (Allin 1999). Only the giraffe of Charles X, later named Zarafa, reached Europe in good health, entering France via Marseille in 1826 (Allin 1999). After some weeks of quarantine, Zarafa continued its journey by foot towards Paris, accompanied by Étienne Geoffroy Saint-Hilaire (Geoffroy Saint-Hilaire 1827). It lived 18 years at the Ménagerie du Jardin des Plantes of the MNHN (Rigoulet 2012). By comparing Zarafa with southern giraffes collected by Levaillant (1797) and Delalande (1822), Geoffroy SaintHilaire was the first zoologist to distinguish two giraffe species: Giraffa camelopardalis (Linnaeus, 1758) from Sennar and Ethiopia and the "Girafe du Cap" from the Cape Region (Geoffroy Saint-Hilaire 1827). Some years later, Lesson (1842) classified the southern species under the name Giraffa capensis (Lesson, 1842). With the exploration of Africa during the $19^{\text {th }}$ century, many giraffes were collected 
for European natural history museums, which led to the description of several subspecies, primarily based on differences in coat pattern and colouration (see Table 1). Lydekker (1914) recognized two giraffe species and 14 subspecies: Giraffa camelopardalis, represented by six subspecies in northern sub-Saharan Africa (G. c. camelopardalis, G. c. antiquorum (Jardine, 1835), G. c. congoensis Lydekker, 1903, G. c. cottoni Lydekker, 1904, G. c. peralta Thomas, 1898 and G. c. rothschildi Lydekker, 1903), two subspecies in East Africa (G. c. thornicrofti Lydekker, 1911 and G. c. tippelskirchi Matschie, 1898) and four subspecies in southern Africa (G. c. angolensis Lydekker, 1903, G. c. capensis (Lesson, 1842), G. c. infumata Noack, 1908 and G. c. wardi Lydekker, 1904); and Giraffa reticulata Thomas, 1901, including two subspecies from Kenya (G. r. reticulata de Winton, 1899 and G. r. nigrescens Lydekker, 1911). This classification was adopted by most scientists over the next decades, until Dagg (1962) proposed a new classification recognizing only the single species Giraffa camelopardalis, including 13 subspecies (see Fig. 1A). Ansell (1968) agreed with the existence of a single species, but recognized only nine subspecies: G. c. camelopardalis, G. c. angolensis, G. c. antiquorum, G. c. peralta, G. c. giraffa (Boddaert, 1784), G. c. reticulata, G. c. rothschildi, G. c. thornicrofti and G. c. tippelskirchi (Fig. 1B, see Table 1 for synonymized subspecies). This view was adopted (sometimes with minor changes) in most subsequent classifications (e.g., Dagg \& Foster 1976; Wilson \& Mittermeier 2011; Ciofolo \& Le Pendu 2013; Muller et al. 2018).

A mitochondrial fragment, covering the cytochrome $b$ gene $(C y t b)$, tRNA genes for Threonine and Proline, and the $5^{\prime}$ region of the control region $(\mathrm{CR})$ (length $=1764$ base pairs $(\mathrm{bp})$ ), was sequenced for giraffes of seven of the nine recognized subspecies $(\mathrm{n}=23 ; G$. c. camelopardalis and G. c. thornicrofti missing) in the molecular study of Hassanin et al. (2007). Their phylogenetic analyses have indicated that northern giraffes constitute a monophyletic group, distinct from that of southern giraffes. Brown et al. (2007) analysed two mitochondrial fragments (cytochrome $b$, tRNA genes for Threonine and Proline, and $5^{\prime}$ region of the $\mathrm{CR}$; length $=1705 \mathrm{bp}$ ) and 14 nuclear microsatellite loci for many wild

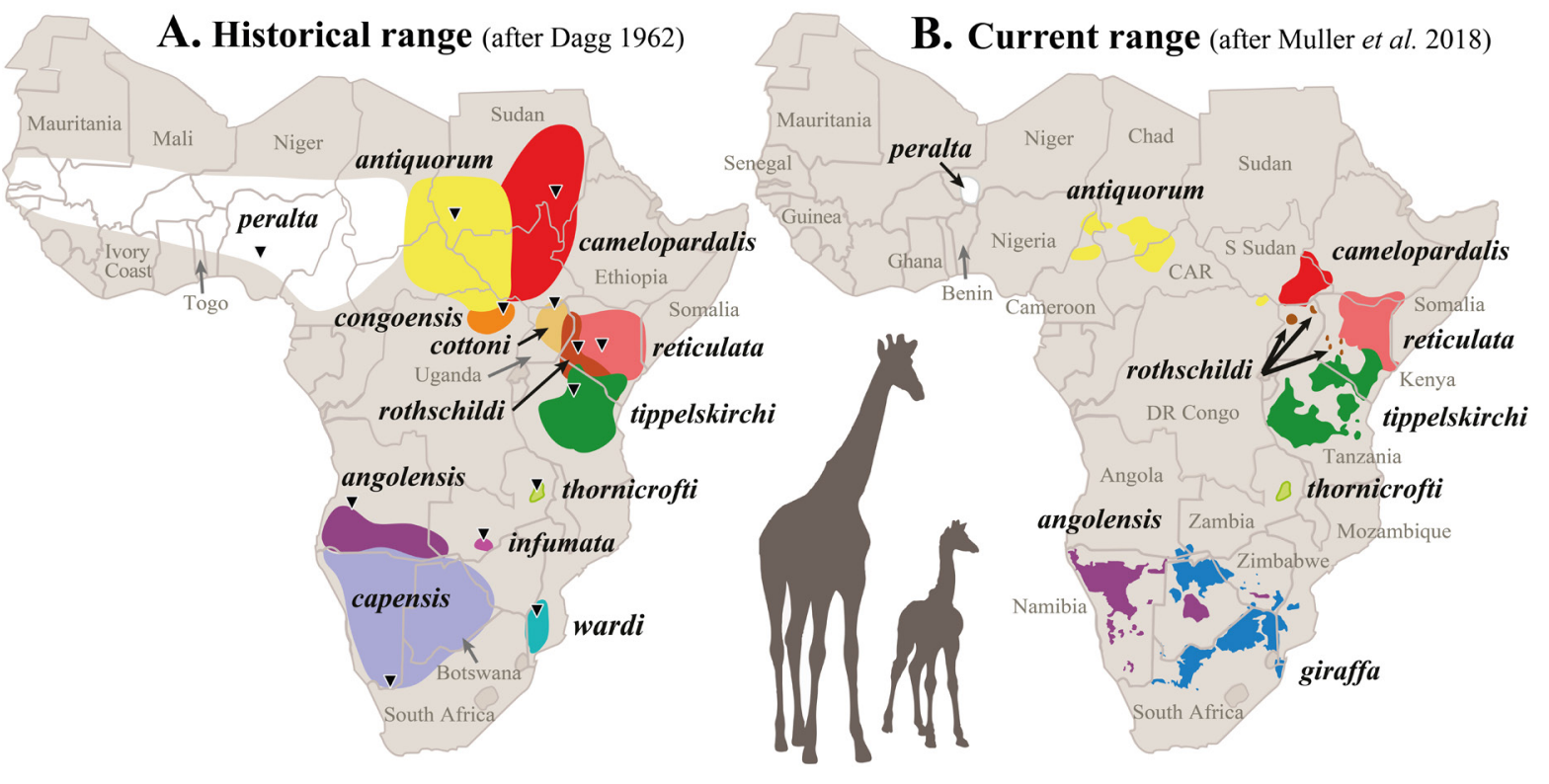

Fig. 1. Distribution range of giraffe subspecies. A. Within historic times (after Dagg 1962). B. At present (after Muller et al. 2018). The subspecies are distinguished by different colours on both maps, whereby the assignment of colours for the nine currently recognized subspecies (B) was modified from https://giraffeconservation.org/giraffe-species/. The type locality for each subspecies is indicated by a triangle in map A and detailed in Table 1. 





individuals ( $\mathrm{n}=266$ and 381, respectively) from six subspecies (G. c. camelopardalis, G. c. antiquorum and G. c. thornicrofti missing). They suggested the existence of at least six species, corresponding to Giraffa angolensis, G. giraffa, G. peralta, G. reticulata, G. rothschildi and G. tippelskirchi. Bock et al. (2014) analysed a similar mitochondrial fragment of 102 giraffes (cytochrome $b+5^{\prime}$ region of the $\mathrm{CR}$; length $=1555 \mathrm{bp}$ ) and proposed to synonymize the two subspecies $G$. c. thornicrofti and G. c. tippelskirchi, because they have very similar mitochondrial haplotypes. Fennessy et al. (2016) and Winter et al. (2018b) recognized four giraffe species based on the analyses of a mitochondrial fragment (cytochrome $b+5$ ' region of the CR; length $=1556 \mathrm{bp}$ ) and several nuclear introns ( 7 and 21 , respectively): G. camelopardalis (northern giraffe), G. giraffa (southern giraffe), G. reticulata (reticulated giraffe) and G. tippelskirchi (Masai giraffe). More recently, Petzold \& Hassanin (2020) re-examined all available molecular data using different methods of species delimitation that rely on different species concepts, i.e., multispecies coalescent (Genealogical species concept, Baum \& Shaw 1995), population genetic (Genetic species concept, Baker \& Bradley 2006) and phylogenetic (Phylogenetic species concept, Donoghue 1985) methods. Their results provided strong support for the distinction of three species only, corresponding to G. camelopardalis (including reticulata), G. giraffa and G. tippelskirchi. This species classification is the one adopted herein. For convenience, we will use the following subspecies names: G. camelopardalis camelopardalis, G. c. antiquorum, G. c. congoensis, G. c. cottoni, G. c. peralta, G. c. reticulata, G. c. rothschildi, G. giraffa giraffa, G. g. angolensis, G. g. capensis, G. g. wardi, G. tippelskirchi tippelskirchi and G. t. thornicrofti.

The present study provides further insights on the genetic diversity among giraffe subspecies. It is important to note that most subspecies previously identified using phenotypic features were found monophyletic with mitochondrial data, i.e., G. c. antiquorum, G. c. peralta, G. c. rothschildi, G. g. giraffa, G. g. angolensis, and G. t. thornicrofti. This does not mean that subspecies are fully isolated taxa, as gene flow between subspecies can be maintained through dispersing males, at least occasionally. However, the philopatry of females is apparently at the origin of some morphological characteristics. In this perspective, we report herein the first mitochondrial sequences for several key museum specimens. These include the famous giraffe Zarafa from Sennar, which is assumed to belong to the type population of G. c. camelopardalis, two giraffes from Abyssinia, several historical specimens collected by Levaillant and Delalande, which were described as G. g. capensis by Lesson (1842), as well as topotypes of the subspecies G. c. congoensis and G. c. cottoni, and two giraffes collected in Senegal during the $19^{\text {th }}$ century (see Material and methods for more details). Our three main objectives were: (1) to compare for the first time past giraffe populations with current biodiversity; (2) to include in the phylogenetic analyses some subspecies described in former classifications in order to re-evaluate their taxonomic status; and (3) to estimate divergence times among giraffes in order to provide a more comprehensive phylogeographic scenario.

\section{Material and methods}

\section{Museum specimens}

Bone, tooth, faeces or skin samples were obtained from 41 giraffes, comprising samples from 19 museum specimens (Table 2, illustrated in Fig. 2, sample localities shown in Fig. 3). Among the most important samples are three specimens of the subspecies G. g. capensis (Lesson, 1842) collected by Levaillant (1797) and Delalande (1822), the first southern taxon investigated by the scientific community, with populations formerly found north of the Orange River (Levaillant 1797; see Fig. 3), a topotype of the subspecies G. c. cottoni Lydekker, 1904 collected by Powell-Cotton in the Lado enclave (left bank of the White Nile) in northwest Uganda and South Sudan, five specimens from the Haut-Uele Province in Democratic Republic of the Congo, which may be representatives of the type population of the subspecies G. c. congoensis described from the type locality Dungu (Lydekker 1903), two giraffes collected in Bakel (Senegal) by Girardin in 1830, which according to Dagg (1962) may represent the most western distribution point of G. c. peralta (Fig. 1A), and three specimens from the type locality of the nominate subspecies G. c. camelopardalis, i.e., the famous Zarafa from Sennar and two giraffes from Abyssinia (Ethiopia). 


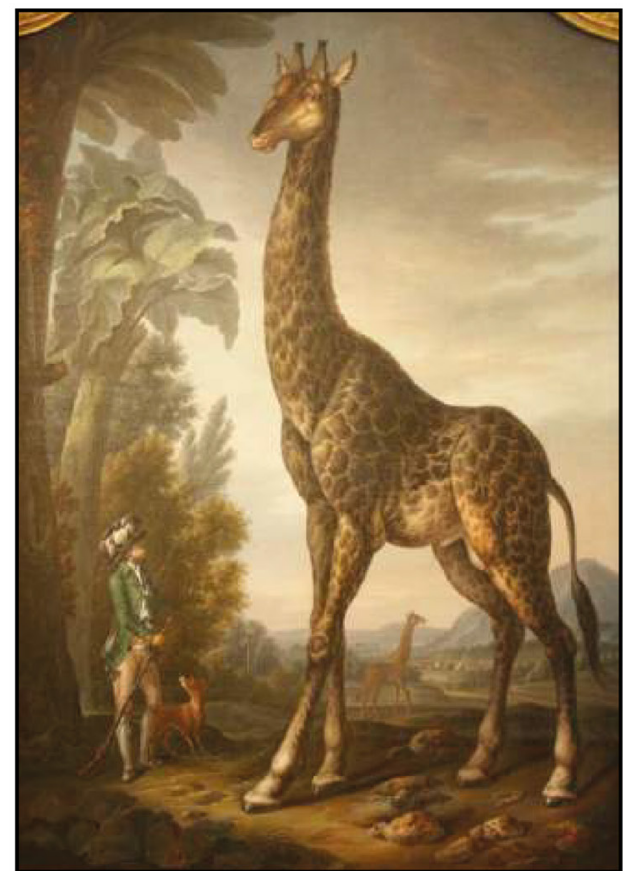

A.

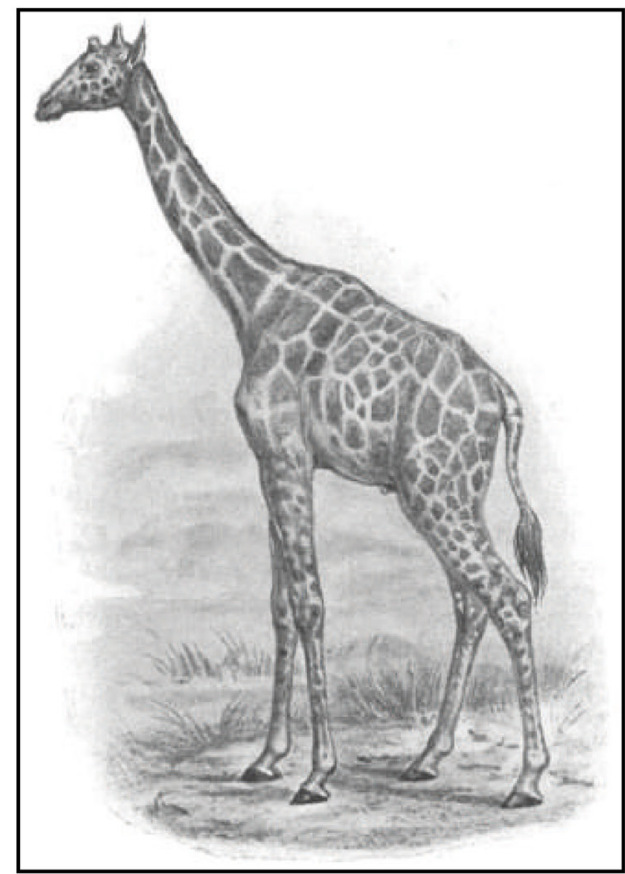

C.

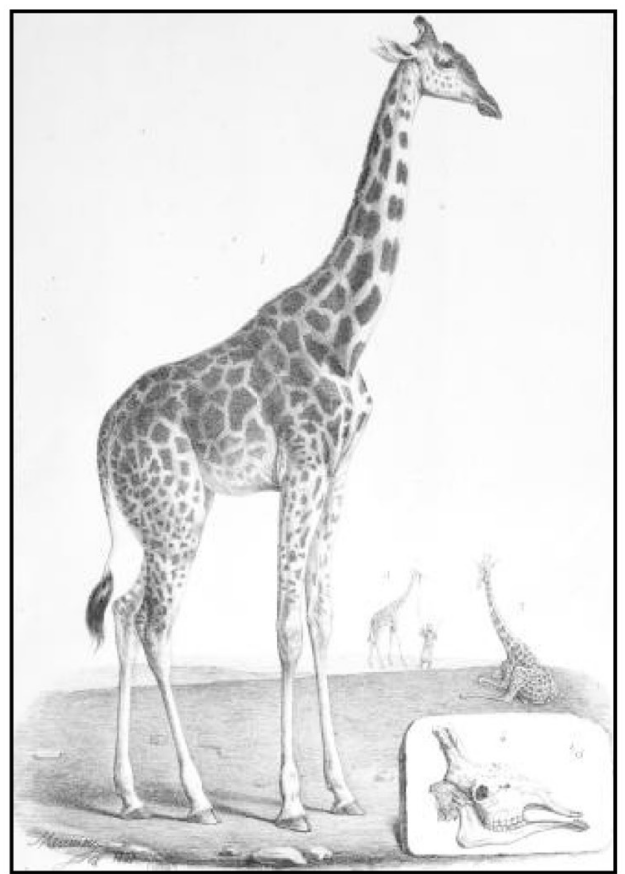

B.

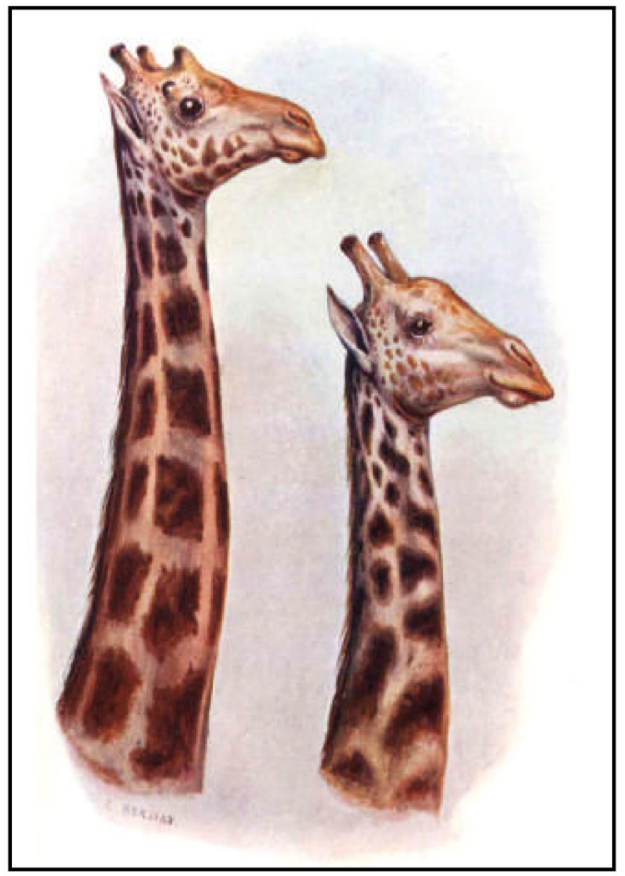

D.

Fig. 2. Illustrations of historical giraffe specimens. A. The 'Giraffe of Levaillant', anonymous painting made in the late $18^{\text {th }}$ century and early $19^{\text {th }}$ century, exhibited in 'hôtel de Magny', Jardin des Plantes in Paris (France). B. The 'Giraffe from Sennaar', representing a lithography of Zarafa (MNHN-1845-211) and the skull of a giraffe from the Cape region (Geoffroy Saint-Hilaire 1827). C. Drawing of the holotype of Giraffa camelopardalis congoensis Lydekker, 1903 (RMCA-452), housed in the Royal Museum of Central Africa, Tervuren (Belgium) (Lydekker 1904). D. Head drawings of the holotypes of G. c. cottoni Lydekker, 1904 (NHMUK-1904.1.21.1, left) and G. g. wardi Lydekker, 1904 (NHMUK-1903.11.18.1, right) (Lydekker 1914). 
Table 2. Museum specimens sequenced in this study (subspecies assignations have been made by morphological characters or distribution range). $\mathrm{DRC}=$ Democratic Republic of the Congo; SA = South Africa.

\begin{tabular}{|c|c|c|c|c|}
\hline Voucher & Subspecies & Collector, Date & Locality & $\mathbf{N}^{\circ}$ Accession \\
\hline IRSNB-IG19076 & $?$ & Unknown, 1953 & $\begin{array}{l}\text { Anglo-Egyptian Sudan } \\
\text { (Sudan/South Sudan) }\end{array}$ & MT542052 \\
\hline MNHN-A10753 & peralta? & Gérardin, 1830 & Bakel, Senegal & MT542037 \\
\hline MNHN-A10617 & peralta? & Gérardin, 1830 & Bakel, Senegal & MT542038 \\
\hline MNHN-1896-45 & capensis & Delalande, $1818-1820$ & Cape of Good Hope (SA) & MT542039 \\
\hline MNHN-A10749 & capensis & Delalande, $1818-1820$ & Cape of Good Hope (SA) & MT542040 \\
\hline MNHN-A7977 & capensis & Levaillant, $1783-1785$ & Cape of Good Hope (SA) & MT542041 \\
\hline MNHN-1845-211 & camelopardalis & Mouker Bey, 1824 & Sennar (Sudan) & MT542042 \\
\hline MNHN-A8012 & camelopardalis & Clot Bey, 1843 & Abyssinia (Ethiopia) & MT542043 \\
\hline MNHN-1913-523 & tippelskirchi? & Babault, 1912-1913 & Kenya & MT542054 \\
\hline MHNT-1996.121.2 & camelopardalis & Unknown, 1843 & Abyssinia (Ethiopia) & MT542044 \\
\hline RMCA-21645M & antiquorum & Huese, 1953 & Sarh, Chad & MT542046 \\
\hline RMCA-25672M & congoensis & Poll, 1959 & Gangala, DRC & MT542047 \\
\hline RMCA-25673M & congoensis & Poll, 1959 & Gangala, DRC & MT542048 \\
\hline $\begin{array}{l}\text { RMCA-83.006- } \\
\text { M0553 }\end{array}$ & congoensis & Colyn, 1946 & Garamba Park, DRC & MT542049 \\
\hline RMCA-3748M & congoensis & De Calonne, 1914 & Kapili, DRC & MT542050 \\
\hline RMCA-767M & cottoni & Powell-Cotton, 1908 & $\begin{array}{l}\text { Lado enclave, northwest } \\
\text { Uganda and South Sudan }\end{array}$ & MT542051 \\
\hline RMCA-5956M & congoensis & Pilette, 1923 & North-East Uele, DRC & MT542053 \\
\hline RMCA-2128M & tippelskirchi & Bayer, 1913 & Serengeti-Mara, Kenya & MT542055 \\
\hline ZMB-48222 & $?$ & Unknown & Dikoa, Nigeria & MT542045 \\
\hline
\end{tabular}

\section{Repositories}

IRSNB = Institut royal des Sciences naturelles de Belgique, Brussels, Belgium

NHMUK $=$ Natural History Museum London, United Kingdom

MHNT = Muséum d'histoire naturelle de Toulouse, France

MNHN = Muséum national d'histoire naturelle, Paris, France

RMCA $=$ Royal Museum of Central Africa, Tervuren, Belgium

SMF $\quad=$ Senckenberg Museum Frankfurt, Germany

$\mathrm{ZMB}=$ Museum für Naturkunde Berlin, Germany

\section{DNA extraction, amplification and sequencing}

Total genomic DNA was extracted from 30-50 mg of bone or teeth powder for each sample, using two commercial kits (PrepFiler BTA Forensic DNA Extraction and QIAamp DNA Micro). In agreement with the protocol provided by Rohland \& Hofreiter (2007), DNA extractions from museum samples were performed in a room dedicated to ancient DNA procedure, and multiple negative controls were used during DNA extractions and PCR reactions. We also extracted DNA from 22 extant giraffes from 
Cameroon, Chad, Kenya, South Africa and zoos (Beauval in France and Al Ain in the United Arab Emirates) (Supplementary file 1) using $0.2 \mathrm{~g}$ per faecal sample, following the instructions of the QIAamp DNA Stool Mini Kit (QIAGEN).

A mitochondrial DNA (mtDNA) fragment, covering the complete cytochrome $b$ gene, two tRNA genes (Threonine and Proline) and the 5' part of the control region (D-Loop), was amplified by polymerase chain reaction (PCR) using 15 primer sets, which generate overlapping fragments (detailed in Supplementary file 2). Amplifications were performed on a total volume of $19 \mu 1$, comprising $10 \mu 1$ of SYBR ${ }^{\circledR}$ Green Supermix (BioRAD), $6.8 \mu \mathrm{H}_{2} \mathrm{O}, 0.6 \mu \mathrm{l}$ of each primer $(10 \mu \mathrm{M})$ and $1 \mu \mathrm{l}$ of giraffe DNA per sample, using a CFX Connect Real-Time PCR Detection System thermocycler under the following conditions: $4 \mathrm{~min}$ at $94^{\circ} \mathrm{C}$, followed by $94^{\circ} \mathrm{C}$ for $30 \mathrm{~s}$, then $1 \mathrm{~min}$ at $45-55^{\circ} \mathrm{C}$ followed by $1 \mathrm{~min}$ at $72^{\circ} \mathrm{C}$, ending with a single extension of $72^{\circ} \mathrm{C}$ for $7 \mathrm{~min}$ ( 40 cycles). The PCR products were sent to Eurofins Genomics (Ebersberg, Germany) for forward and reverse direction Sanger sequencing. The electropherograms were edited and assembled to a reference sequence using Sequencher ver. 5.1. (http://www.genecodes.com). All mitochondrial sequences generated for this study were deposited in GenBank (see accession numbers in Table 2 and Supplementary file 1).

\section{Haplotype network}

The 41 newly generated sequences were aligned in Geneious R10 (Biomatters, Auckland, New Zealand) with published mitochondrial sequences available in NCBI. The final alignment of 548 giraffe samples (length $=1742 \mathrm{bp}$ ) was used to construct a median-joining network (Bandelt et al. 1999) with PopArt 1.7 (Leigh \& Bryant 2015). Since PopArt does not consider sites with missing data, the two regions corresponding to tRNA-Thr and tRNA-Pro genes, and the last $35 \mathrm{bp}$ of the D-loop were removed from our alignment because they were not sequenced in most previous studies (Brown et al. 2007; Fennessy et al. 2013, 2016; Bock et al. 2014; Winter et al. 2018a, 2018b).

\section{Phylogenetic analyses based on mitochondrial and nuclear datasets}

The nuclear DNA (nuDNA) dataset of 21 introns published by Fennessy et al. (2016) and Winter et al. (2018b) (accession numbers LT596685-LT598170, MG257969-MG262280) was used to select the 75 sequenced giraffes fulfilling the following three criteria: (1) all the 21 nuclear introns are available; (2) each individual represents a unique nuclear haplotype; and (3) the mitochondrial fragment, including the cytochrome $b$ gene and $5^{\prime}$ region of the control region, is also available (individuals in compliance with the criteria are listed in Supplementary file 3). Heterozygous sites (double peaks) were coded according to the IUPAC code. The mtDNA dataset contains the same 75 individuals and the 13 new haplotypes detected for past populations in this study (see museum specimens indicated in Fig. 4A). Three outgroup species were used to root the giraffe tree: Bos taurus Linnaeus, 1758, Ovis canadensis Shaw, 1804 and Okapia johnstoni Sclater, 1901 (for more details, see Petzold \& Hassanin 2020).

The nuDNA dataset (named nuDNA-78T; length $=17275 \mathrm{bp}$ ) and mtDNA dataset (named mtDNA-91T; length $=1776 \mathrm{bp}$ ) were analysed with probabilistic methods, using the GTR $+\mathrm{I}+\mathrm{G}$ substitution model, as selected in jModeltest ver. 2.1.10 (Darriba et al. 2012) with the Akaike information criterion. Bayesian inferences were conducted in MrBayes ver. 3.2.6 (Ronquist et al. 2012) by calculating the posterior probabilities (PP) after $10^{7}$ Metropolis-coupled MCMC generations, with tree sampling every 1000 generations and a burn-in of $25 \%$. Maximum Likelihood (ML) analyses were performed with PhyML ver. 3.1 (Guindon et al. 2010) and Bootstrap percentages (BP) were calculated after 1000 replicates.

\section{Multispecies coalescent analyses of the nuclear dataset}

The phased alleles of the 21 introns of the nuDNA-78T dataset (see above) were analysed under BEAST ver. 2.4.8 (Bouckaert et al. 2014) to infer a multispecies coalescent (MSC) tree phylogeny. As in Petzold \& Hassanin (2020), the two alleles of the 21 introns were assigned at the level of individuals, 
i.e., for each of the 75 giraffes and the three outgroup taxa. For each of the 21 introns, the substitution model was selected in jModeltest: K80 for OTOF; K80+I for RASSF4; F81 for Clorf74, NOTCH2, SOS1 and UBN2; F81+G for ACP5; HKY for CCT2, COL5A2, CTAGE5, CWF19L1, DDX1, DHX36, MACF 1, NUP155, PLCE1 and USP54; HKY + I for IGF2B1, RFC5 and SAP130; HKY + G for USP33. Analyses were run under the Yule species tree prior for $10^{9}$ generations, sampling trees every 20000 steps.

The. $\log$ files were analysed with Tracer ver. 1.7 (Rambaut et al. 2018) to verify the convergence of model parameters (effective sample size (ESS) $>200$ ). The species tree was summarised as a Maximum Clade Credibility tree in TreeAnnotator ver. 1.10 (Rambaut \& Drummond 2007) discarding 50\% as burn-in and subsequently displayed with Figtree ver. 1.4.4 (http://tree.bio.ed.ac.uk/software/).

\section{Estimation of mitochondrial and nuclear divergence times}

Divergence times among giraffe subspecies were estimated with the nuDNA-78T and mtDNA-91T datasets using the Bayesian approach implemented in BEAST ver. 1.8.4 (Drummond et al. 2012) under the GTR $+\mathrm{G}+\mathrm{I}$ model and assuming a relaxed clock following a lognormal distribution. The BirthDeath speciation process was specified as tree prior and the most recent common ancestor (MRCA) of Giraffa was used as a calibration point, set at $1.1 \pm 0.1$ Mya in agreement with the molecular study of Hassanin et al. (2012) and the fossil record (Harris 1991). Analyses were run with random starting seeds for $10^{8}$ generations, sampling trees every 10000 steps. Tracer ver. 1.7 (Rambaut et al. 2018) was used to visualise the posterior distribution to assess the convergence of model parameters (effective sample size (ESS) > 200). The chronograms were summarised in TreeAnnotator ver. 1.10 (Rambaut \& Drummond 2007) discarding $25 \%$ as burn-in and subsequently displayed with Figtree ver. 1.4.4 (http://tree.bio.ed.ac.uk/software/).

\section{Mitochondrial and nuclear pairwise distances}

The 88 giraffe sequences of the mtDNA-91T dataset were analysed in PAUP* ver. 4.0b10 (Swofford 2003) to calculate nucleotide pairwise distances (p-distances) within and among haplogroups revealed in the haplotype network of Fig. 3. Nucleotide pairwise distances were also calculated for the 75 giraffe sequences of the nuDNA-78T dataset.

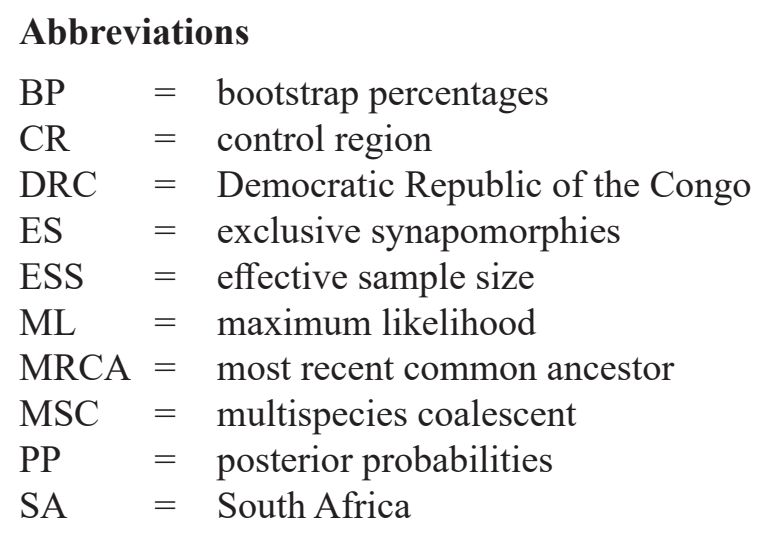

\section{Results}

\section{Haplotype network}

The haplotype network built from the mtDNA sequences of 548 giraffes is shown in Fig. 3. The network reveals three divergent geographic haplogroups separated by more than 30 mutations, named northern $(\mathrm{N})$, southeastern (SE) and southwestern (SW). The northern and southeastern haplogroups can be further divided into subgroups that are separated by at least 10 mutations. 


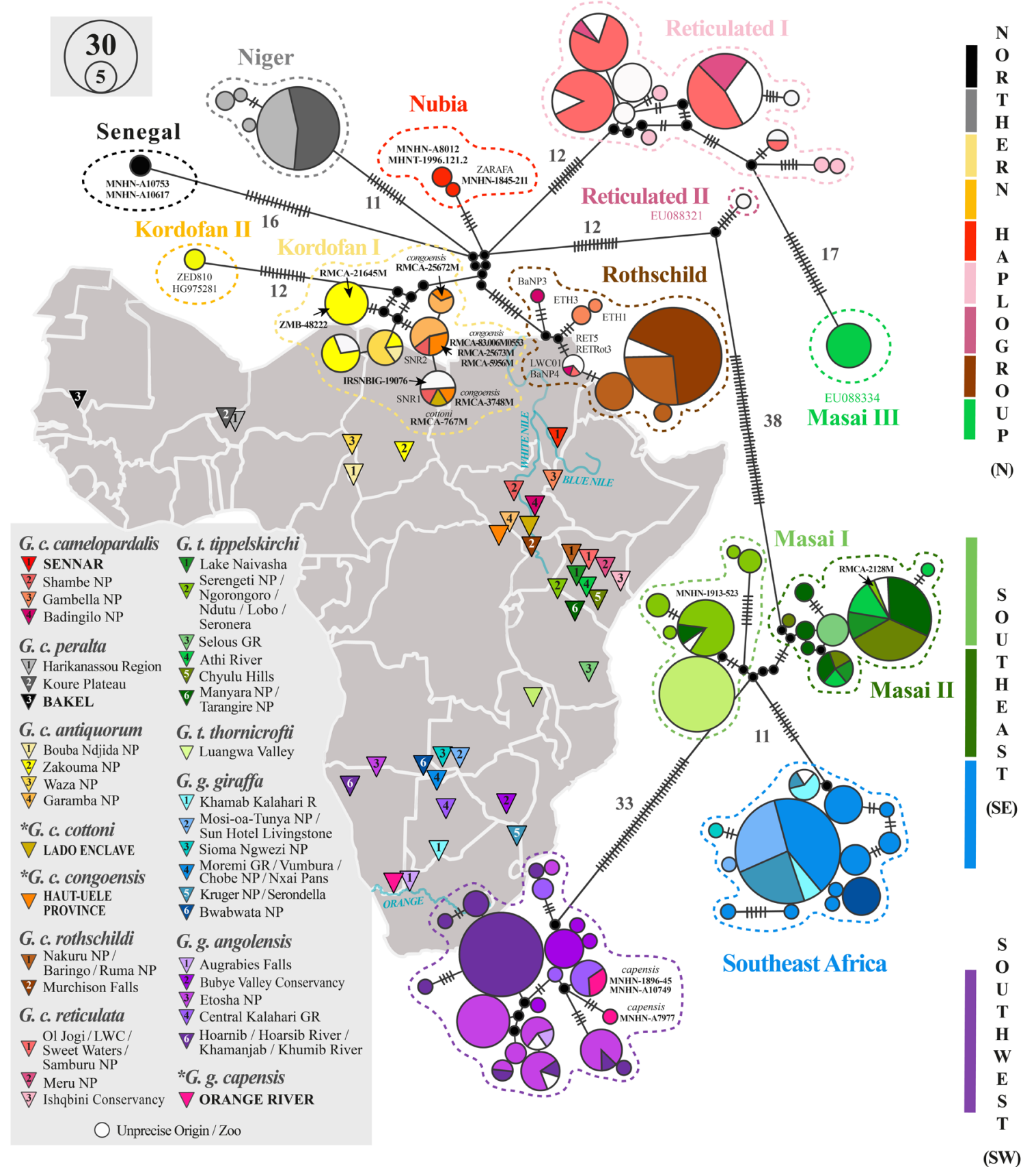

Fig. 3. Median-joining network of mitochondrial haplotypes. The network was constructed in PopART 1.7 (Leigh \& Bryant 2015) based on the mitochondrial sequences of 548 giraffes. The number of mutations between haplotypes is indicated by perpendicular lines on the branches and is specified if greater than 10 . The size of the circles is proportional to the number of individuals sharing a certain haplotype with colours assigned by subspecies. The sample locations are indicated by triangles in the map and highlighted in bold capital letters for museum specimens. The subspecies marked with an asterisk represent formerly recognized subspecies, which were synonymized in recent classifications (e.g., Shorrocks 2016). Historical key specimens are highlighted by the respective abbreviation of the museum and the catalogue number. 
The northern $(\mathrm{N})$ haplogroup includes all giraffes from northern sub-Saharan Africa belonging to the subspecies G. c. camelopardalis, G. c. antiquorum, G. c. peralta, G. c. reticulata and G. c. rothschildi. Within this group, several subspecies do not form clusters, but nine haplogroups separated by at least 10 mutations can be defined: (1) the haplogroup named 'Senegal' is represented by two giraffes collected in Senegal in the $19^{\text {th }}$ century (MNHN-A10753, MNHN-A10617); (2) the haplogroup named 'Niger' comprises the four haplotypes detected in 44 individuals of the subspecies G. c. peralta; (3) the haplogroup named 'Nubia' includes three museum specimens of the subspecies G. c. camelopardalis collected during the $19^{\text {th }}$ century, i.e., Zarafa from Sennar (MNHN-1845-211) and the two giraffes from Abyssinia (MNHN-A8012 and MHNT-1996.121.2); (4) the haplogroup named 'Kordofan I' contains 28 extant giraffes of the subspecies G. c. antiquorum from Cameroon (Bouba Njida NP, Waza NP), Chad (Zakouma NP) and the DRC (Garamba NP), as well as two giraffes assigned to the subspecies G. c. camelopardalis (SNR1, SNR2) by Fennessy et al. (2016) from the Shambe Nature Reserve in South Sudan, three museum specimens collected in southern Chad (RMCA-21645M; locality: Sarh), Sudan (IRSNB-IG19076) and northeastern Nigeria (ZMB-48222; locality: Dikoa), as well as all the five museum specimens assigned to the former subspecies G. c. congoensis (RMCA-25672M, RMCA-25673M, RMCA-3748M, RMCA-5956M, RMCA-83.006-M0553) and the single individual of G. c. cottoni (RMCA-767M); (5) the haplogroup named 'Kordofan II' includes two individuals of the subspecies G. c. antiquorum from Zakouma NP (Chad) sequenced by two independent teams (HG97528: Bock et al. 2014; ZED810: this study); (6) the haplogroup named 'Rothschild' comprises all 75 giraffes assigned to the subspecies G. c. rothschildi (three haplotypes), as well as three reticulated giraffes (subspecies G. c. reticulata) (LWC01 from central Kenya; RET5 and RETRot3 from a German zoo), and five individuals assigned to the subspecies G. c. camelopardalis by Fennessy et al. (2016) (BaNP3, BaNP4, ETH1, ETH2, ETH3); (7) the haplogroup named 'Reticulated I' includes 11 haplotypes detected in 66 individuals of the subspecies G. c. reticulata from Kenya and European zoos; (8) the haplogroup named 'Reticulated II' is only represented by a single haplotype (EU088321) sequenced by Brown et al. (2007) for one giraffe from central Kenya; and (9) the haplogroup named 'Masai III' is only represented by a single haplotype (EU088334) sequenced by Brown et al. (2007) for nine individuals of the subspecies G. t. tippelskirchi from the Athi River (Kenya).

The southeastern (SE) haplogroup comprises giraffes from southeastern Africa belonging to the subspecies G. g. giraffa, G. t. tippelskirchi and G. t. thornicrofti. Three subgroups are separated by more than 10 mutations: (1) the haplogroup named 'Southeast Africa' is represented by 13 haplotypes and 83 individuals found exclusively among members of the subspecies $G$. g. giraffa; (2) the haplogroup named 'Masai I' includes the single haplotype shared by all 34 representatives of the subspecies $G$. t. thornicrofti and three haplotypes of G. t. tippelskirchi giraffes, comprising 24 extant individuals sampled in northern Tanzania (Serengeti National Park (NP); Manyara NP) and a museum specimen (MNHN-1913-523) collected in Kenya; and (3) the haplogroup named 'Masai II' includes eight haplotypes of the subspecies G. t. tippelskirchi detected in 58 extant individuals collected over the whole sampling area and a museum specimen (RMCA-2128M) sampled in the Serengeti-Mara in southern Kenya.

The southwestern (SW) haplogroup contains only giraffes from southwestern Africa, i.e., the 21 haplotypes of 95 individuals assigned to the subspecies G. g. angolensis and the three specimens of the former subspecies G. g. capensis collected by Levaillant (1797) and Delalande (1822) from the Cape Region: one represents a formerly unknown haplotype (MNHN-A7977), and the two others (MNHN1896-45, MNHN-A10749) are identical with haplotypes of giraffes currently found in the Central Kalahari Game Reserve (Botswana).

\section{Comparison between mtDNA and nuDNA phylogenetic trees}

The Bayesian trees, ML trees and BEAST chronograms reconstructed from the mtDNA-91T and nuDNA$78 \mathrm{~T}$ datasets are available in the Supplementary files 4, 5, 6, 7 and 8. Note that the northern haplogroups 
'Reticulated II' and 'Masai II' (Fig. 3) were excluded from the analyses because nuclear introns are not available. In Fig. 4, the chronogram inferred from the mtDNA-91T dataset (Fig. 4A) is compared to the MSC species-tree reconstructed from the nuDNA-78T dataset (Fig. 4B). The divergence times estimated with the nuDNA-78T dataset under BEAST were reported for the main nodes of the MSC species-tree.

The monophyly of Giraffa obtained maximal support $\left(\mathrm{PP}_{\text {Bayes/BEAST }}=1 ; \mathrm{BP}=100\right)$ in all analyses, and the genus can be diagnosed by 65 exclusive synapomorphies (ES) in the mtDNA-91T dataset and 164 ES in the nuDNA-78T dataset.

All phylogenetic analyses of the mtDNA-91T dataset show a dichotomy separating northern giraffes $(G$. camelopardalis $)\left(\mathrm{PP}_{\text {Bayes } / \mathrm{BEAST}}=1 ; \mathrm{BP}=98\right)$ from southern giraffes $(G$. giraffa + G. tippelskirchi $)$ $\left(\mathrm{PP}_{\text {Bayes }}=0.98 ; \mathrm{PP}_{\mathrm{BEAST}}=0.99 ; \mathrm{BP}=77\right)$. Molecular dating estimates calculated from the mtDNA-91T
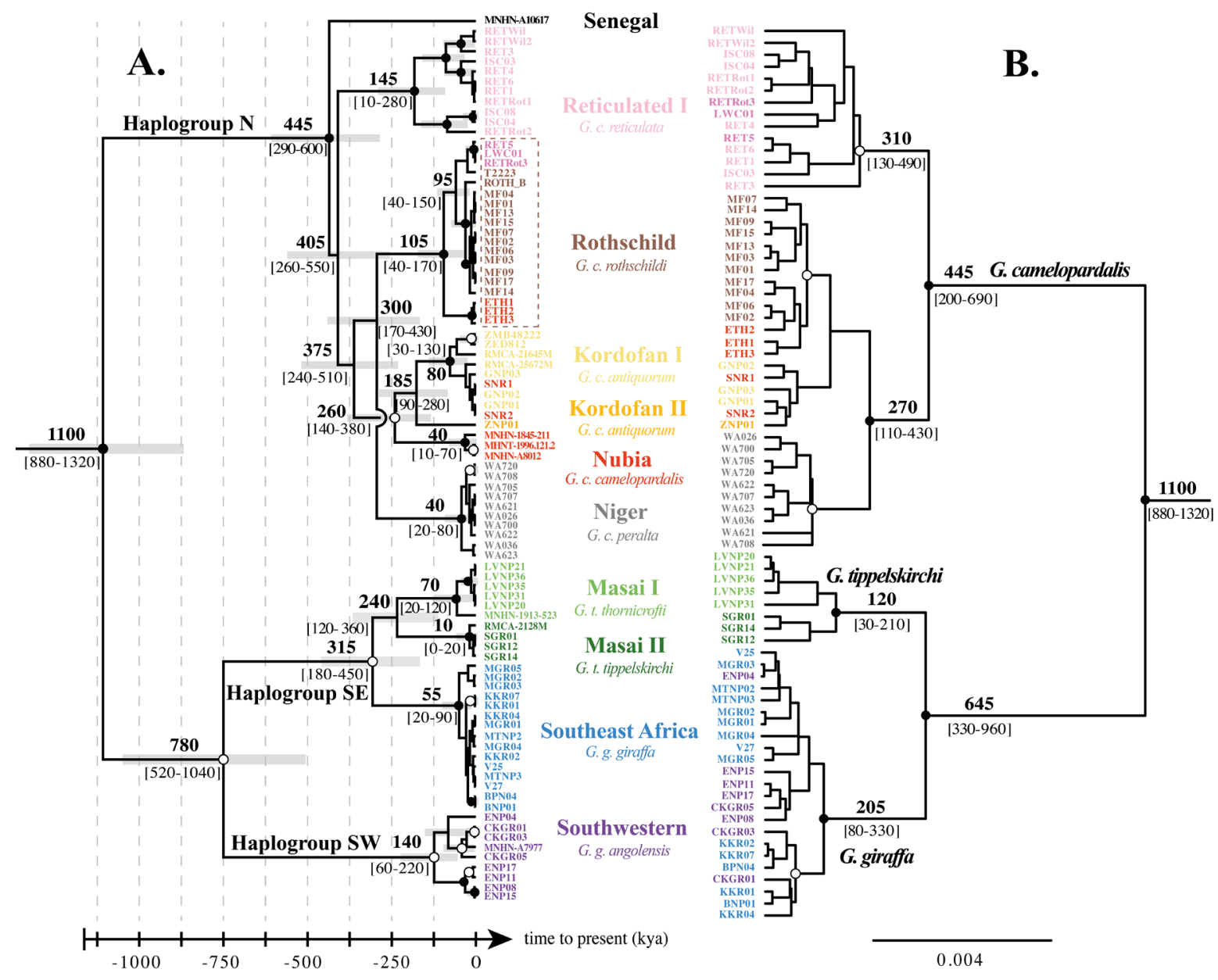

Fig. 4. Comparison of mitochondrial and nuclear divergence time estimates. A. Chronogram inferred from the mtDNA dataset using BEAST ver. 1.8.4 (Drummond et al. 2012). The mean divergence times are reported on the nodes, and the horizontal grey bars show $95 \%$ confidence intervals. B. Phylogram reconstructed from the multispecies coalescent analysis of the nuDNA dataset using *BEAST ver. 2.4.8 (Bouckaert et al. 2014). Divergence times estimated in BEAST ver. 1.8.4 (Drummond et al. 2012) are reported on the nodes to allow comparison with the mtDNA chronogram (Supplementary file 8). Nodes with a white circle were supported by $\mathrm{PP}_{\mathrm{BEAST}} \geq 0.95$, whereas nodes with a black circle were supported by both $\mathrm{PP}_{\text {BEAST }} \geq 0.95$ and $\mathrm{BP}_{\mathrm{ML}} \geq 80$. 
dataset suggest $780 \pm 260$ kya for the MRCA of southern giraffes and $445 \pm 155$ kya for the MRCA of northern giraffes. All mitochondrial haplogroups identified in the network of Fig. 3 are found to be monophyletic and can be diagnosed by several ES (Supplementary file 9). The haplogroup N $\left(\mathrm{PP}_{\text {Bayes/BEAST }}=1 ; \mathrm{BP}=98\right.$; six ES) contains seven subgroups corresponding to 'Nubia' $\left(\mathrm{PP}_{\text {Bayes/BEAST }}=\right.$ 1 ; $\mathrm{BP}=99)$, 'Kordofan I' $\left(\mathrm{PP}_{\text {Bayes } / \mathrm{BEAST}}=1 ; \mathrm{BP}=80\right.$; one ES), its sister-group, i.e., 'Kordofan II' $\left(\mathrm{PP}_{\text {Bayes }}=0.97 ; \mathrm{PP}_{\mathrm{BEAST}}=0.81 ; \mathrm{BP}=48\right.$; two ES), 'Niger' $\left(\mathrm{PP}_{\text {Bayes } / \mathrm{BEAST}}=1 ; \mathrm{BP}=100\right.$; three $\left.\mathrm{ES}\right)$, 'Rothschild' ( $\mathrm{PP}_{\text {Bayes/BEAST }}=1 ; \mathrm{BP}=99$; one ES), 'Reticulated I' $\left(\mathrm{PP}_{\text {Bayes/BEAST }}=1 ; \mathrm{BP}=100\right.$; two ES) and 'Senegal', which is represented by a single haplotype (five ES). Southern giraffes can be further separated in two main geographic haplogroups, SE and SW. The MRCA of haplogroup SE was dated at $315 \pm 135$ kya $\left(\mathrm{PP}_{\text {Bayes }}=0.99 ; \mathrm{PP}_{\text {BEAST }}=1 ; \mathrm{BP}=77\right.$; one $\left.\mathrm{ES}\right)$. It comprises the three subgroups 'Southeast Africa' $\left(\mathrm{PP}_{\text {Bayes/BEAST }}=1 ; \mathrm{BP}=99\right.$; two ES), 'Masai I' ( $\mathrm{PP}_{\text {Bayes/BEAST }}=1 ; \mathrm{BP}=92$; three ES) and 'Masai II' $\left(\mathrm{PP}_{\text {Bayes/BEAST }}=1 ; \mathrm{BP}=98\right.$; one ES $)$. The MRCA of haplogroup SW was dated at $140 \pm 80$ kya. It was highly supported in the BEAST analysis $\left(\mathrm{PP}_{\mathrm{BEAST}}=1\right)$, but less supported in the two other analyses $\left(\mathrm{PP}_{\text {Bayes }}=0.44 ; \mathrm{BP}=36\right)$. It can be diagnosed by three ES.

In agreement with the mtDNA analyses, all nuDNA analyses support the separation of northern giraffes $($ G. camelopardalis $=$ haplogroup $\mathrm{N})\left(\mathrm{PP}_{\mathrm{Bayes} / \mathrm{BEAST} / \mathrm{BEAST}}=1 ; \mathrm{BP}=100\right.$; eight $\left.\mathrm{ES}\right)$ from southern giraffes (G. giraffa + G. tippelskirchi) $\left(\mathrm{PP}_{\text {Bayes/BEAST/*BEAST }}=1 ; \mathrm{BP}=56\right.$; four ES) (see Supplementary file 10 for ES). The MRCA of G. camelopardalis was dated at $445 \pm 245 \mathrm{kya}$. The nuDNA-78T dataset does not provide strong signals for relationships within haplogroup N. However, the subspecies G. c. reticulata is found to be monophyletic $\left(\mathrm{PP}_{\mathrm{Bayes} / \mathrm{BEAST} / *_{\mathrm{BEAST}}}=1 ; \mathrm{BP}=38\right)$, as it includes all individuals of the mitochondrial haplogroup 'Reticulated I', as well as the three individuals of the mitochondrial haplogroup 'Rothschild' morphologically assigned to G. c. reticulata (RET5, RETRot3, LWC01). Other subspecies of $G$. camelopardalis are grouped together $\left(\mathrm{PP}_{\mathrm{Bayes} / \mathrm{BEAST} / *_{\mathrm{BEAST}}}=1 ; \mathrm{BP}=96\right)$. Within this group, the subspecies G. c. peralta (= mitochondrial haplogroup 'Niger') is found monophyletic in the ML tree (BP= $66)$ and MSC species-tree $\left(\mathrm{PP}_{* \text { BEAST }}=0.98\right)$, but polyphyletic in other Bayesian trees, as two individuals (WA026, WA708) cluster with individuals of the subspecies G. c. antiquorum and G. c. rothschildi $\left(\mathrm{PP}_{\text {BEAST }}=0.63 ; \mathrm{PP}_{\text {Bayes }}=0.59\right)$. In the MSC species-tree (Fig. 4B), the subspecies G. c. rothschildi can be considered as monophyletic $\left(\mathrm{PP}_{* \mathrm{BEAST}}=1\right)$ if three giraffes from western Ethiopia $($ ETH1-3), geographically assigned to G. c. camelopardalis in a previous study, are included into this taxon. Similarly, the subspecies G. c. antiquorum can be considered as monophyletic $\left(\mathrm{PP}_{{ }_{\text {BEAST }}}=0.92\right)$ if two giraffes from Shambe NP - South Sudan (SNR1 and SNR2), previously assigned to G. c. camelopardalis, are included into this taxon. The MRCA of southern giraffes was dated at $645 \pm 315 \mathrm{kya}$. This group can be further divided into two taxa corresponding to the species G. giraffa $\left(\mathrm{PP}_{\text {Bayes/BEAST } / *_{\mathrm{BEAST}}}=1 ; \mathrm{BP}=100\right.$; $14 \mathrm{ES})$ and G. tippelskirchi $\left(\mathrm{PP}_{\text {Bayes/BEAST } /{ }^{*} \text { BEAST }}=1 ; \mathrm{BP}=100\right.$; seven ES). The species G. giraffa includes individuals from the mitochondrial haplogroups 'SW' and 'Southeast Africa'. The MRCA of G. giraffa was dated at $205 \pm 125 \mathrm{kya}$. The species G. tippelskirchi contains individuals of the mitochondrial haplogroups 'Masai I' and 'Masai II', which are found to be reciprocally monophyletic in the BEAST trees, but with low support $\left(\mathrm{PP}_{\mathrm{BEAST} / *_{\mathrm{BEAST}}}=0.45 / 0.53\right.$ and $\mathrm{PP}_{\mathrm{BEAST} / *_{\mathrm{BEAST}}}=0.74 / 0.53$, respectively $)$. The MRCA of G. tippelskirchi was dated at $120 \pm 90$ kya.

\section{Mitochondrial and nuclear pairwise distances}

The mtDNA-91T and nuDNA-78T datasets were used to calculate nucleotide pairwise distances (Table 3 and Table 4, respectively).

The mean mitochondrial distances between the three main haplogroups N, SE and SW range from $2.80 \%$ (SE vs SW) to $4.51 \%$ (SE vs N). Within haplogroup N, mean distances between the seven subgroups are comprised between $0.96 \%$ ('Kordofan I' vs 'Nubia') and 1.99\% ('Kordofan II' vs 'Senegal'). The genetic distances between the West African subgroups 'Niger' and 'Senegal' are comprised between 1.74\% (WA708 vs MNHN-A10617) and 1.93\% (WA036 vs MNHN-A10617). The distances between 


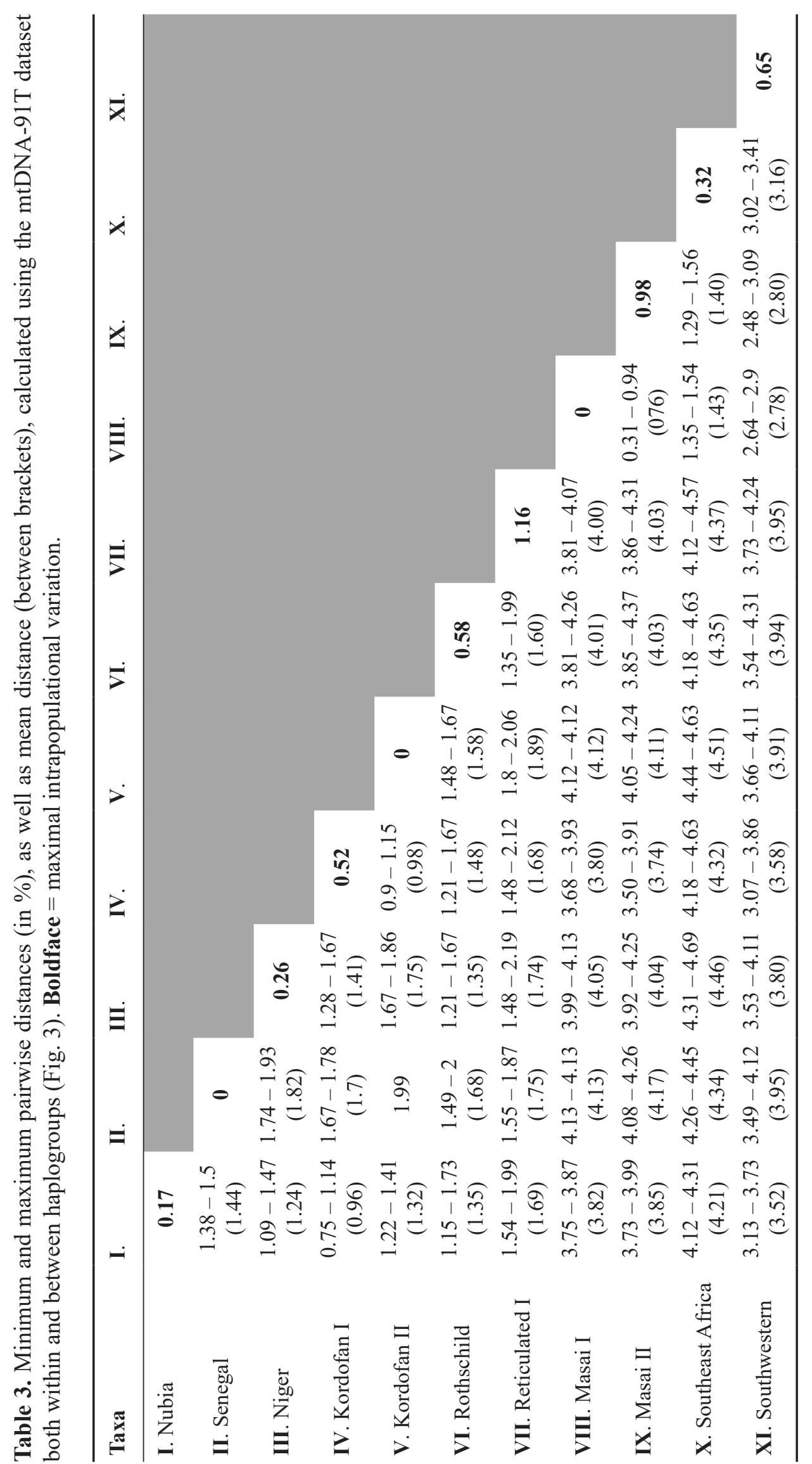




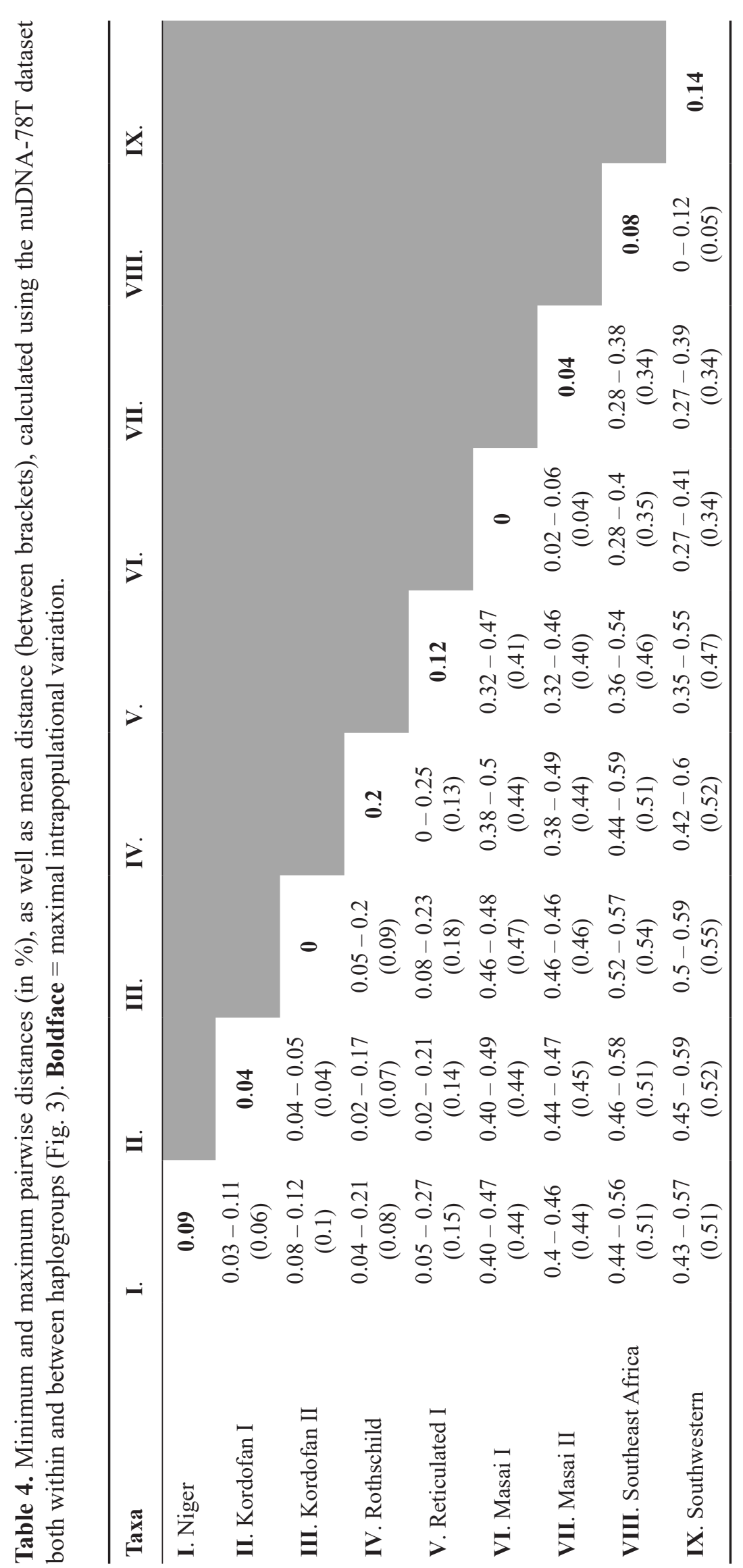


museum specimens of G. c. camelopardalis (subgroup 'Nubia') and the five individuals previously assigned to G. c. camelopardalis (Fennessy et al. 2016; Winter et al. 2018b) range from 0.89\% (MNHN$1845-211$ vs SNR1) to $1.73 \%$ (MNHN-A 8012 vs ETH1). The three reticulated giraffes (RET5, RETRot3, LWC01) from the mitochondrial subgroup 'Rothschild' are highly divergent from reticulated giraffes of the subgroup 'Reticulated I', i.e., between 1.35\% (RETWil vs LWC01) and 1.67\% (ISC08 vs RETRot3). Within haplogroup SE, similar distances were found between members of the three subgroups 'Masai I', 'Masai II' and 'Southeast Africa': from 0.31\% (MNHN-1913-523 vs LVNP20) to 0.94\% (RMCA$2128 \mathrm{M}$ vs LVNP36) for 'Masai I' vs 'Masai II'; from 1.35\% (KKR01 vs LVNP20) to $1.54 \%$ (BNP03 vs LVNP36) for 'Masai I' vs 'Southeast Africa'; from 1.29\% (KKR01 vs SGR01) to 1.56\% (MGR04 vs RMCA-2128M) for 'Masai II' vs 'Southeast Africa'. Within haplogroup SW, the distances range from 0\% (ENP11 vs ENP08) to 0.65\% (ENP11 vs MNHN-A7977).

The mean nuclear distances between the three species of Giraffa are comprised between $0.35 \%$ (G. giraffa vs G. tippelskirchi) and 0.5\% (G. giraffa and G. camelopardalis). Within G. camelopardalis, minimal distances between subspecies range from $0.01 \%$ between the subspecies G. c. antiquorum and G. c. rothschildi (GNP01 vs ETH3) to $0.03 \%$ between G. c. antiquorum and G. c. peralta (SNR1 vs WA036), between G. c. reticulata and G. c. rothschildi (RET3 vs ETH2) or between G. c. peralta and G. c. rothschildi (WA036 vs MF03). The highest distances between subspecies range from $0.1 \%$ between G. c. antiquorum and G. c. peralta (ZNP01 vs WA621) or between G. c. peralta and G. c. rothschildi (WA708 vs MF07) to $0.2 \%$ between G. c. reticulata and G. c. rothschildi (ISC04 vs WA708), between G. c. peralta and G. c. reticulata (WA708 vs ISC04) or between G. c. antiquorum and G. c. reticulata (ZNP01 vs ISC04). Within G. tippelskirchi, distances between the two subgroups Masai I and Masai II range from $0.02 \%$ (LVNP36 vs SGR14) to $0.06 \%$ (LVNP31 vs SGR01). Within G. giraffa, intraspecific distances range from $0 \%$ (ENP04 vs ENP11) to 0.12\% (CKGR03 vs ENP08).

\section{Discussion}

\section{Diversification of giraffes during the Pleistocene epoch}

The first fossil remains related to extant giraffes date back to 1 Mya and were found in West Turkana (East Africa) (Harris 1991), which is in agreement with molecular dating estimates of the MRCA of Giraffa based on complete mitochondrial genomes (Hassanin et al. 2012: 1.1 Mya). This corresponds to one of the most arid periods of the Pleistocene epoch (de Menocal 2004), suggesting that the associated expansion of the savannah may have promoted the split between northern and southern giraffes.

Among southern giraffes, the subsequent divergence between the species G. giraffa and G. tippelskirchi took place at $645 \pm 315$ kya with nuclear data or $780 \pm 260$ kya with mtDNA data. Around $800 \mathrm{kya}$, the landscape was shaped by a strongly humid interglacial period, which caused in southwestern Africa the development of a complex hydrographical network nourished by the Okavango and the Zambezi Basin, culminating in the evolution of the Paleo-lake Makgadikgadi (Goudie 2005; Moore et al. 2012). These newly formed physical barriers may have impeded gene flow between giraffes separated by the Zambezi River, with G. tippelskirchi in the North and G. giraffa in the South.

The rapid diversification of the northern species G. camelopardalis into several subspecies was dated at $445 \pm 155$ kya with the mtDNA dataset and $445 \pm 245$ kya with the nuDNA dataset. These estimates fall into an unusually long interglacial period, which might have been associated with milder savannah conditions (Yin \& Guo 2007), favouring the radiation of northern subspecies. The humid conditions led further to the development of a hydrographical network in Niger, with the rise of water levels of Mega Lake Chad, but also in East Africa, with the extension of the White Nile to the proportion of a Paleolake (Williams et al. 2003) and the origin of Lake Victoria at around 400 kya (Johnson et al. 2000). The 
establishment of this drainage system in East Africa may have isolated (at least temporarily) several giraffe populations, favouring their subsequent diversification at the subspecies level.

\section{The giraffes of the Nile: G. c. camelopardalis, G. c. antiquorum and G. c. rothschildi}

Linnaeus (1758) described the species Cervus camelopardalis based on the description published by Belon du Mans (1553), who saw several living giraffes in the "castle of Cairo", Ray (1693), who refers to Belon du Mans, and Hasselquist (1757), who examined a skin and wrote that giraffes live "in the forests" of Sennar and Ethiopia (indicated as type localities by Linnaeus). Around 1750, the Sultanate of Sennar was located in the current Sudan and covered the regions surrounding the cities of Khartoum and Sennar in the northern parts of the White and Blue Niles. At that time, Ethiopia was smaller than today: bordering southeastern Sennar, it included the regions surrounding the city of Gondar and southern parts of the Blue Nile and its source, the Lake Tana. All first reports on giraffes were based on animals captured by Egyptians, including the giraffes offered to Frederick II (1245), Lorenzo de Medici (1487), and Charles X (1827), as well as the giraffes held captive in Cairo described by Belon du Mans (1553) and the skins studied by Hasselquist (1757). All these giraffes have been collected by exploring the southern regions close to the borders of the Blue and White Niles. Today, the countries crossed by the two main tributaries of the Nile are, from north to south, Sudan, Ethiopia, South Sudan, northeastern DRC and Uganda. In this area, Lydekker (1914) recognized the five following subspecies: G. c. camelopardalis, G. c. antiquorum, G. c. congoensis, G. c. cottoni and G. c. rothschildi (Fig. 1A). Several of these subspecies were, however, synonymized in subsequent classifications: G. c. rothschildi was treated as a synonym of G. c. camelopardalis (East 1998); G. c. congoensis was considered as the synonym of G. c. camelopardalis (Ansell 1968; Dagg 1971) or G. c. antiquorum (Ciofolo \& Le Pendu 2013; Dagg 2014; Shorrocks 2016; Fennessy \& Marais 2018); and G. c. cottoni was ranged into G. c. rothschildi (Ansell 1968). To better understand the taxonomy of giraffes, we included in this study several museum specimens of the $18^{\text {th }}$ and $19^{\text {th }}$ centuries collected within the type localities of the subspecies G. c. camelopardalis, G. c. congoensis and G. c. cottoni.

Fennessy et al. (2016) and Winter et al. (2018b) analysed seven giraffe samples supposed to belong to the nominate subspecies G. c. camelopardalis (Linnaeus 1758), because they were collected in South Sudan and Ethiopia, two countries where the subspecies is still possibly present according to the IUCN (Wube et al. 2018). These samples include SNR1 and SNR2, which were collected on the left bank of the White Nile in South Sudan (Shambe NP), BaNP3 and BaNP4, which were collected on the right bank of the White Nile in South Sudan (Bandingilo NP), and ETH1, ETH2 and ETH3, which were collected in western Ethiopia (Gambella NP), far from both White and Blue Nile rivers (see Figs 3, 5). Our network and phylogenetic analyses based on the mitochondrial sequences of giraffes (Figs 3, 4A) show that SNR giraffes belong to the haplogroup 'Kordofan I', whereas BaNP and ETH giraffes belong to the haplogroup 'Rothschild'. In agreement with mtDNA results, our analyses of nuclear introns confirm that SNR giraffes belong to the subspecies G. c. antiquorum, whereas ETH giraffes belong to the subspecies G. c. rothschildi. Based on similar phylogenetic results, Fennessy et al. (2016) have, however, concluded that the subspecies G. c. rothschildi should be synonymized with G. c. camelopardalis, as previously suggested by some authors (Kingdon 1997; East 1998). Our analyses of museum specimens, however, support another taxonomic interpretation. Indeed, the two mtDNA haplotypes sequenced from three specimens of the $19^{\text {th }}$ century assigned to G. c. camelopardalis (haplogroup Nubia, Figs 3,4 ) form a well-supported monophyletic group ( $\mathrm{PP}=1 ; \mathrm{BP}=99)$, distinct from all other haplogroups previously identified (nucleotide distance $>0.75 \%$ from Kordofan I; $1.22 \%$ from Kordofan II; $>1.15 \%$ from Rothschild): the first haplotype was obtained from the famous Zarafa (MNHN 1845-211), which was captured in 1824 near the mountains located south of the city of Sennar (Salze 1827), probably close to the boundary between Sudan and Ethiopia; the second haplotype was sequenced in two giraffes collected in 'Abyssinia' (Ethiopian Empire), which both arrived in France in 1843 (MNHN-A8012 and MNHT1996.121.2). Zarafa was collected near the Blue Nile, but we do not know if it was captured on the left 
bank or on the right bank of the river. During the $19^{\text {th }}$ century, several explorers have mentioned the presence of many giraffes in the region between the Blue Nile and Tekezé/Atbara rivers in southeastern Sudan (eastern Sennar) and northern Ethiopia (Abyssinia) (Combes \& Tamisier 1838; Baker 1880). Since the haplotype from Sennar is highly similar to the haplotype from Abyssinia (1 mutation), we suggest that the subspecies G. c. camelopardalis was endemic to this region. However, we cannot completely exclude that G. c. camelopardalis was also present in the region of western Sennar between the White Nile and Blue Nile, delimited in the south by the Sobat River in the west, followed in the east by the Baro River and Ethiopian Highlands (Fig. 5).

The taxonomic status of other subspecies related to the Nile was problematic. For instance, some authors have treated G. c. rothschildi as a synonym of G. c. camelopardalis (Ciofolo \& Le Pendu 2013; Fennessy et al. 2016). However, our phylogeographic analyses support that G. c. camelopardalis and G. c. rothschildi are two distinct subspecies, and that populations of G. c. rothschildi are found in eastern South Sudan, western Ethiopia, northeastern Uganda and northwestern Kenya, a biogeographical region delimited by the White Nile river in the west, by the Sobat River (or alternatively the Blue Nile) in the north, Ethiopian Highlands in the east and a discontinuous barrier in the south, including Lake Victoria (Fig. 5). Our results therefore corroborate previous hypotheses that giraffes avoid to cross

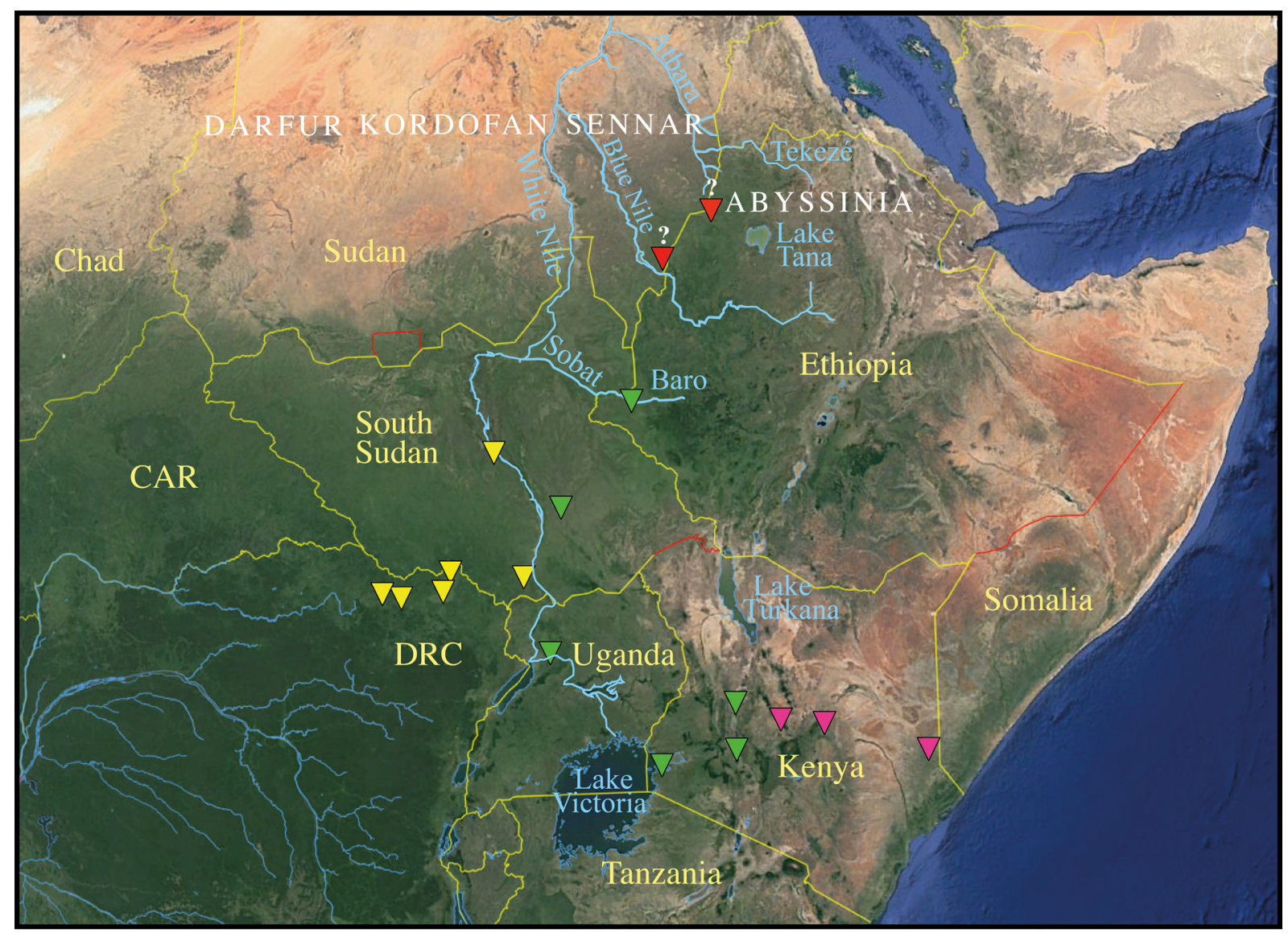

Fig. 5. Giraffe subspecies of the Nile region. The map (extracted from Google Earth; https://www.google.com/intl/de/earth/) shows the geographical barriers (rivers and mountains) that may have isolated (at least temporarily) the subspecies Giraffa camelopardalis camelopardalis (Linnaeus, 1758) (red), G. c. antiquorum (Jardine, 1835) (yellow), G. c. rothschildi Lydekker, 1903 (green) and G. c. reticulata de Winton, 1899 (magenta). The question mark refers to the uncertain geographic origin of Zarafa (left) and the two specimens from Abyssinia (right) (see Discussion for more details). 
high mountains (Happold 1978; Dagg 2014) and large rivers (MacClintock 1973; Henderson \& Naish 2010). This might concern in particular females living in nursery herds with their calves (Bercovitch \& Berry 2010), which tend to avoid the potential risk of overcoming biogeographic barriers (Petzold \& Hassanin 2020). In eastern central Kenya, populations of G. c. rothschildi and G. c. reticulata can be found in sympatry (Kingdon 1997) and field observations of intermediate phenotypes have suggested occasional gene flow between these two subspecies (Stott \& Selsor 1981; Kingdon 1997). In the mtDNA tree, three individuals of G. c. reticulata (RET5, RETRot3, LWC01) cluster within the haplogroup 'Rothschild' (Fig. 4A), whereas they are related to other individuals of G. c. reticulata in the nuDNA tree (Fig. 4B). This mito-nuclear discordance suggests that a mitochondrial introgression occurred from G. c. rothschildi to G. c. reticulata at $96 \pm 55$ kya (Fig. 4B).

Our phylogeographic analyses based on mtDNA sequences suggest that all populations located on the left bank of the White Nile belong to the subspecies G. c. antiquorum. Indeed, the topotype specimens of G. c. congoensis from the Haut-Uele Province in northeastern DRC (RMCA-25672M, RMCA-25673M, RMCA-3748M, RMCA-5956M, RMCA-83.006-M0553) and G. c. cottoni from the Lado enclave in northwest Uganda and South Sudan (RMCA-767M) cluster within the haplogroup 'Kordofan I', suggesting that the two subspecies G. c. congoensis and G. c. cottoni should be synonymized with G. c. antiquorum.

\section{A new subspecies from Senegal}

In 1898, Lieutenant R.H. McCorquodale shot the first ever recorded giraffe in Nigeria (McCorquodale 1898; Fig. 1A). He sent the skull to Mr. Oldfield Thomas at the British Museum in London, who described the subspecies G. c. peralta based on the "elongation of the face [...] with a very large spatulate nasal opening $[\ldots]$ and a more vertically upright direction of the ossicones" compared to other northern and southern races (Thomas 1898). The type locality is indicated as "southeast of the junction of the Benue and Niger" (Thomas 1898). However, we agree with Lydekker (1904) that Lokoja (Nigeria), which is located in the $\mathrm{V}$-shaped area to the north of the confluence of the Niger and Benue rivers, is a more probable type locality, because the Benue and Niger rivers may have acted as barriers against giraffe dispersal towards the south of Nigeria (Happold 1969).

During the $20^{\text {th }}$ century, giraffes were then recorded in other countries of West Africa, such as Senegal, Gambia, Mali, Ghana, and Niger (Sidney 1965; Happold 1969, 1978; Nežerková et al. 2004). Consequently, the distribution of G. c. peralta was supposed to cover a large area from Senegal in the west towards the western part of the Central African Republic in the east (Fig. 1A; Dagg 1962; Happold 1969). However, populations have severely decreased over the last decades, because of poaching, habitat loss, increasing aridity (Dagg \& Foster 1976) and outbreaks of rinderpest (Roeder et al. 2013), and the West African giraffe is now considered regionally extinct in Burkina Faso, Guinea, Mali, Mauritania and Senegal (Fennessy et al. 2018). The mitochondrial study of Hassanin et al. (2007) suggested that giraffes found in Cameroon, Chad and the Central African Republic rather belong to the subspecies G. c. antiquorum. At present, G. c. peralta is listed as endangered, only represented by 607 individuals in Niger (Zabeirou 2017).

Our results show that the past diversity of West African giraffes was greater than previously assumed, as the mtDNA haplotype sequenced from two museum specimens (MNHN-A10617 and MNHN-A10753) collected in Senegal (Bakel) by Girardin in 1830 (Malte-Brun \& Malte-Brun 1839) is distinct from other subspecies of the haplogroup $\mathrm{N}$ by at least $1.38 \%$ and can be diagnosed by five ES (Supplementary file 9). We assume that the Sahara Desert in the north, rainforests in the south and the Niger River in the east may have acted as physical barriers limiting gene flow between giraffes from Senegal and those from Niger and Nigeria (G. c. peralta). Both differ considerably in the colouration and pattern of the coat. The Niger giraffe can be recognized by its pale almond coat covered with numerous light brown spots 
differing in shape and getting smaller on the hindquarters, whereas the beige coat of the Senegal giraffe (Fig. 6) shows large dark brown patches with a clear contour and almost uniform in size on neck, trunk and hindquarters. All these elements indicate therefore that giraffes from Senegal should be placed into their own subspecies that will be formally described below. Unfortunately, the subspecies is now extinct, as the last giraffes of Senegal were killed in the 1970's (Vincke et al. 2005).

\section{Taxonomic status of the giraffes collected in the Cape of Good Hope during the $18^{\text {th }}$ and $19^{\text {th }}$ centuries}

Boddaert (1784) was the first to describe a southern giraffe from the Cape of Good Hope under the name 'Camelopardalis giraffa', based on specimens with no precise locality housed in the Prince of Orange Museum in The Hague and Naturalis museum in Leiden (Netherlands). At that time, the Cape of Good Hope, also known as the Cape colony, was a Dutch colony covering most of the presentday South Africa, excepting the northeastern regions (see map of Levaillant \& de La Borde 1790). Levaillant (1797) and Delalande (1822) caught several giraffes in the vicinity of the Orange River (Fig. 3), which were assigned to the species Giraffa capensis by Lesson (1842) with the type locality "Cape of Good Hope". Some decades later, Lydekker (1904) recognized three subspecies of southern giraffes: capensis for giraffes from the 'Cape colony and adjacent districts'; wardi for giraffes from Northern Transvaal (present-day Limpopo and Pretoria, northeastern South Africa); and angolensis for giraffes from Angola. This taxonomic view was adopted by most zoologists over the next decades, until Ansell (1968) proposed a new classification with only two subspecies: angolensis Lydekker, 1903 for giraffes from Angola and giraffa (Boddaert, 1784) (Fig. 1B) for giraffes from South Africa, the latter including capensis Lesson, 1842 and wardi Lydekker, 1904 as synonyms.

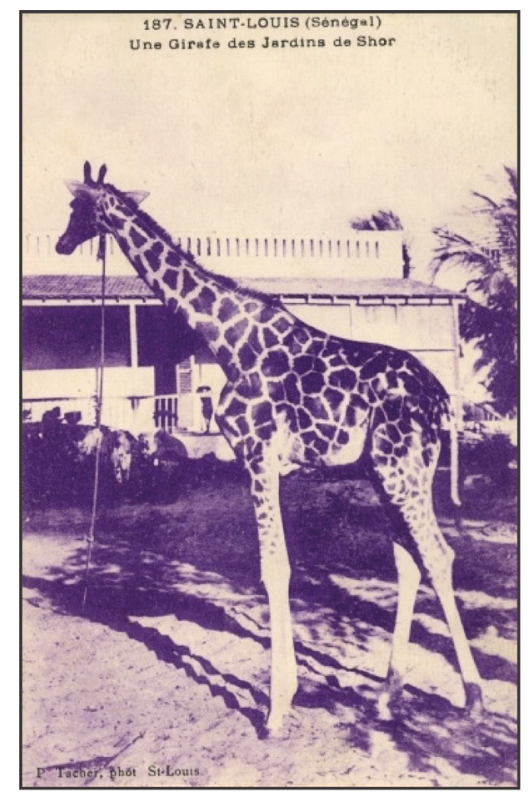

A

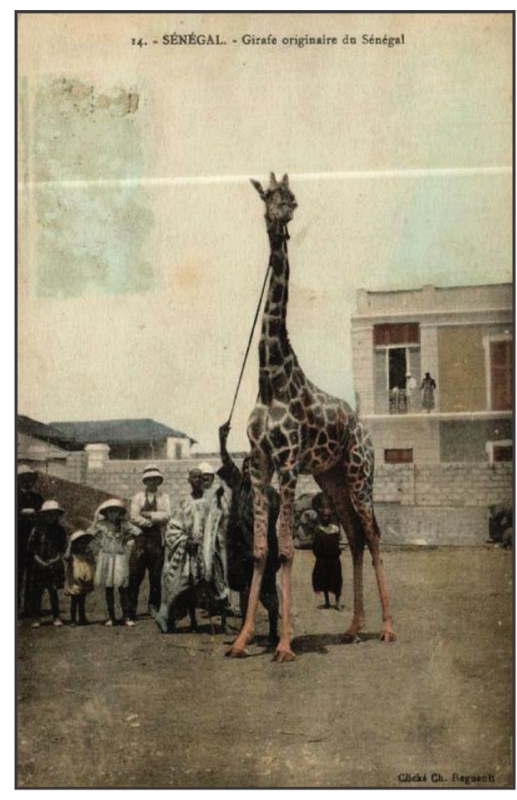

B

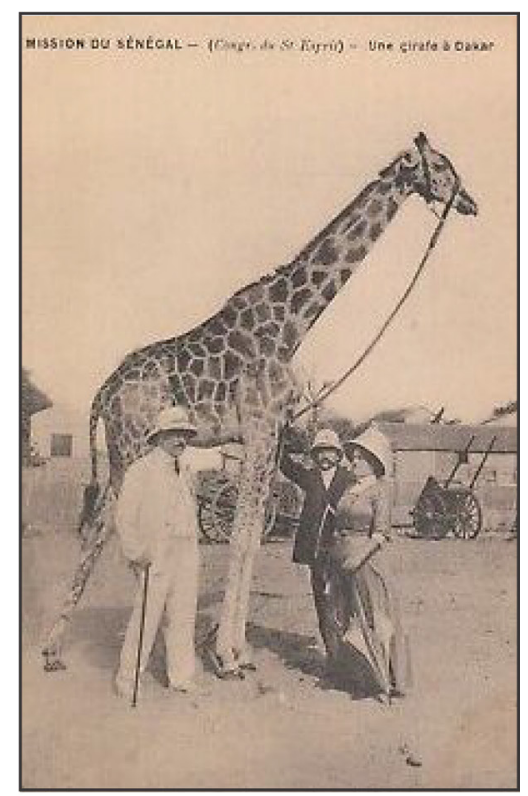

C

Fig. 6. Postcards of the Senegal giraffe at the beginning of the $20^{\text {th }}$ century. A. "Une Girafe des Jardins de Shor", photo taken by P. Tacher in 1909 (https://oldthing.ch/AK-Saint-Louis-Une-Girafe-des-Jardinsde-Shor-Giraffe-im-Gehege-0033371252). B. "Girafe originaire du Sénégal” (https://www.ebay.fr/sch/ Cartes-postales/914/i.html?cmd=Blend\%7CBlend\&_nkw=girafe). C. "Mission du Sénégal - girafe à Dakar" (https://www.picclickimg.com/d/400/pict/192836173148_/CPA-DAKAR--SENEGALMISSION-DU-SENEGAL-UNE.jpg). 
Our mtDNA analyses of three 'Cape giraffes' collected by Levaillant (1797) and Delalande (1822) (MNHN-A7977, MNHN-1896-45, MNHN-A10749) show that the two haplotypes fall within the haplogroup SW, which also contains all haplotypes detected for the subspecies G. g. angolensis, including the southwestern giraffes from Angola and central Botswana, as well as an isolated population from Zimbabwe (Winter et al. 2018a). The haplogroup SW is genetically distinct by 3\% from individuals of the haplogroup 'Southeast Africa', which includes giraffes from northeastern South Africa, southern Mozambique, northern Botswana, southern Zambia and southern Zimbabwe. The results indicate therefore that the subspecies G. g. angolensis and G. g. capensis should be synonymized with G. g. giraffa (giraffes of the Cape of Good Hope), whereas the subspecies G. g. wardi should be rehabilitated for southeastern giraffes.

\title{
Taxonomic treatment
}

The molecular investigation of key specimens of European museum collections provided the unique opportunity to reveal past giraffe biodiversity through the inclusion of (possibly) extinct populations. Our results have strong taxonomic implications for the classification of giraffes at the subspecies level. We propose the following revision of the classification of the genus Giraffa based on molecular (Petzold \& Hassanin 2020; this study: see Supplementary files 9 and 10) and morphological diagnosis criteria (Lydekker 1914).

\author{
Class Mammalia Linnaeus, 1758 \\ Order Artiodactyla Owen, 1848 \\ Family Giraffidae Gray, 1821 \\ Genus Giraffa Brisson, 1762
}

Giraffa camelopardalis (Linnaeus, 1758)

\section{Diagnosis}

Shanks white, presence of occipital horns, five ES in the Cytb gene: $186 \mathrm{~A}=>\mathrm{G}, 288 \mathrm{G}=>\mathrm{A}, 333 \mathrm{~A}=>\mathrm{G}$, $597 \mathrm{C}=>\mathrm{T}$, $924 \mathrm{C}=>\mathrm{T}$; one ES in the CR: $462 \mathrm{~A}=>\mathrm{G}$; two ES in the CTAGE5 intron: $570 \mathrm{~T}=>\mathrm{C}$, $705 \mathrm{C}=>\mathrm{G}$; two ES in the CWF19L1 intron: $263 \mathrm{~T}=>\mathrm{G}, 264 \mathrm{~T}=>\mathrm{G}$; one ES in the DDX1 intron: 268 dACAT; one ES in the DHX36 intron: 50 iGTT; two ES in the $S O S 1$ intron: $103 \mathrm{~T}=>\mathrm{C}, 118 \mathrm{G}=>\mathrm{A}$.

\section{Type material examined}

Neotype (here designated)

ETHIOPIA • 1 specimen (skin and complete skeleton); Abyssinia; MHNT-1996.121.2.

\section{Other specimens}

ETHIOPIA 11 specimen (skull and skeleton parts); Abyssinia; MNHN-A8012.

SUDAN • 1 specimen (skull), "Zarafa”; Sennar; MNHN-1845-211.

\section{Distribution}

Niger, Chad, Cameroon, Central African Republic, Democratic Republic of Congo, South Sudan (holotype), Uganda, Somalia, Ethiopia (neotype), Kenya.

\section{Remarks}

The holotype designation was based on a living giraffe illustrated by Belon du Mans (1553), which was not sampled for a museum collection. The neotype herein designated represents the most complete 
specimen (skin and complete skeleton) and has been the first giraffe to be dissected, providing several anatomical drawings (see Joly \& Lavocat 1845).

Giraffa camelopardalis camelopardalis (Linnaeus, 1758)

Camelopardalis aethiopicus Ogilby, 1837: 134.

Camelopardalis biturigum Duvernoy, 1844: 12, fig. 4.

Giraffa camelopardalis typica Bryden, 1899: 489, plate XIV.

\section{Diagnosis}

Front of the face sparsely and sides fully spotted, similar pattern to reticulata but with chestnut or sandy patches.

\section{Past distribution}

Probably extinct, former range between the Blue Nile and Tekezé/Atbara rivers in southeastern Sudan (eastern Sennar) and northern Ethiopia (Abyssinia).

\section{Giraffa camelopardalis antiquorum (Jardine, 1835)}

Giraffa camelopardalis sennaariensis Trouessart, 1898: p.902.

Giraffa camelopardalis congoensis Lydekker, 1903: 386.

Giraffa camelopardalis cottoni Lydekker, 1904: 207, fig. 1.

\section{Diagnosis}

Spots on the upper part of the fore-limbs and the thighs broken up in a number of very small and irregular ones.

\section{Type material}

\section{Holotype}

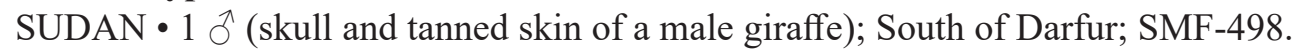

\section{Paratype}

SUDAN $\bullet 1$ (skull and tanned skin of a female giraffe); South of Darfur; SMF-497.

\section{Distribution}

Cameroon, Chad, Central African Republic, Democratic Republic of Congo, South Sudan (holotype).

\section{Remarks}

The holotype designation was based on the information provided by Rüppel (1826), who collected two specimens in North Africa. Both specimens can be meanwhile found in the collection of the Senckenberg Museum Frankfurt (Germany) listed as SMF-498 (skull and tanned skin, male): unspecified type and SMF-497 (skull and tanned skin, female): paratype.

Giraffa camelopardalis peralta Thomas, 1898

\section{Diagnosis}

Elongated skull, large spatulate nasal opening, vertically upright direction of the ossicones, fawncoloured patch below the ears, white sparsely spotted occipital region; two ES in the Cytb gene: 219 $\mathrm{C}=>\mathrm{T}, 1080 \mathrm{C}=>\mathrm{T}$, and one ES in the CR: $23 \mathrm{~A}=>\mathrm{G}$. 


\section{Type material}

\section{Holotype}

NIGERIA 1 specimen (skull and bones of right fore and left hind limb); Lokoja; NHMUK-1898.2.18.1.

\section{Distribution}

Niger.

\section{Remarks}

The type locality has originally been assigned to the junction between the Niger and Benue rivers in Nigeria, but it was corrected in this study to Lokoja (Nigeria) north of the confluence of the Niger and Benue rivers in accordance with Happold (1969).

Giraffa camelopardalis reticulata de Winton, 1899

Giraffa camelopardalis australis Rhoads, 1896: 518.

Giraffa hagenbecki Knottnerus-Meyer, 1910: 800.

Giraffa reticulata nigrescens Lydekker, 1911: 484.

\section{Diagnosis}

Deep liver-red colour with a coarse network of narrow white lines, one ES in the Cytb gene: $795 \mathrm{C}=>\mathrm{T}$; one $\mathrm{ES}$ in the $\mathrm{CR}: 94 \mathrm{C}=>\mathrm{T}$.

\section{Type material}

\section{Holotype}

KENYA - 1 specimen (skull, scalp and piece of neck skin); East of Loroghi mountains; NHMUK-1897.1.30.1.

\section{Distribution}

Southern Ethiopia, Kenya (holotype), Somalia.

\section{Giraffa camelopardalis rothschildi Lydekker, 1903}

\section{Diagnosis}

Lower parts of the legs pure white and unspotted, spots show a tendency to split up into stars, occipital pair of ossicones, one ES in the CR: $129 \mathrm{~T}=>\mathrm{C}$.

\section{Type material}

\section{Holotype}

KENYA • 1 specimen (mounted skin); Guasin-gisha Plateau east of Mount Elgon; NHMUK-1903.4.15.1.

\section{Distribution}

Western Ethiopia, Kenya (holotype), Uganda, South Sudan. 
Giraffa camelopardalis senegalensis Petzold, Magnant \& Hassanin, subsp. nov. urn:1sid:zoobank.org:act:838C1DB1-59BA-49DD-B5AA-F5432F36B112

\section{Diagnosis}

Beige ground colour covered with dark brown spots following a reticulated pattern separated by narrow lines, skull features detailed in Blainville (1864), one ES in the $C y t b$ gene: $732 \mathrm{~A}=>\mathrm{G}$; four ES in the CR: $92 \mathrm{dC}, 95 \mathrm{~A}=>\mathrm{G}, 359 \mathrm{C}=>\mathrm{T}, 463 \mathrm{~A}=>\mathrm{G}$.

\section{Type material examined}

Holotype (here designated)

SENEGAL • 1 specimen (skeleton); Bakel; MNHN-A10617.

\section{Past distribution}

Probably extinct, former range extended over Senegal (holotype) and potentially Gambia, Mauritania and Mali.

\section{Giraffa tippelskirchi Matschie, 1898}

\section{Diagnosis}

Faint or strongly stellate form of the patches, absence of occipital horns, seven ES in the UBN2 intron: $48 \mathrm{dA}, 209$ iCATAATATATTTAATATATTTAATATTTAATAA, $243 \mathrm{~T}=>\mathrm{A}, 318 \mathrm{G}=>\mathrm{C}, 332 \mathrm{~T}=>\mathrm{G}$, $504 \mathrm{~A}=>\mathrm{C}, 623 \mathrm{C}=>\mathrm{T}$

\section{Type material}

Lectotype (here designated)

TANZANIA • 1 specimen (skull and skin); Lake Eyasi; ZMB-084951.

\section{Distribution}

Kenya, Tanzania (lectotype), Zambia.

\section{Remarks}

Matschie (1898) mentions two different specimens as syntypes, but the second cannot be found in the collection catalogue and might be considered as lost.

Giraffa tippelskirchi tippelskirchi Matschie, 1898

Giraffa schillingsi Matschie, 1898: 79.

\section{Diagnosis}

Stellate formed spots, shanks olive-coloured and spotted down to the hoofs, anterior horn less developed, one $\mathrm{ES}$ in the Cytb gene: $1033 \mathrm{C}=>\mathrm{T}$.

\section{Distribution}

Southern Kenya, Tanzania. 
Giraffa tippelskirchi thornicrofti Lydekker, 1911

\section{Diagnosis}

Low and conical anterior horn, grey colour and scattered spotting of the sides of the face, fawn shanks, three ES in the CR: $39 \mathrm{~A}=>\mathrm{G}, 272 \mathrm{~T}=>\mathrm{C}, 336 \mathrm{~T}=>\mathrm{A}$; two ES in the IGF2BI intron: $60 \mathrm{C}=>\mathrm{T}, 304$ $\mathrm{G}=>$ A.

\section{Type material}

\section{Holotype}

ZAMBIA • 1 specimen (skin); Petauke district; NHMUK-1910.10.17.1.

\section{Distribution}

Luangwa Valley in Zambia.

Giraffa giraffa (Boddaert, 1784)

\section{Diagnosis}

Anterior horn rudimentary, shanks coloured and fully spotted, three ES in the Clorf74 intron: $24 \mathrm{~A}=>\mathrm{T}$, $33 \mathrm{~A} \Rightarrow \mathrm{G}, 825 \mathrm{C}=>\mathrm{G}$; three ES in the DHX36 intron: $127 \mathrm{G}=>\mathrm{A}, 449 \mathrm{dAT}, 498 \mathrm{~A}=>\mathrm{G}$; one ES in the IGF2B1 intron: $45 \mathrm{G}=>\mathrm{A}$; one ES in the UBN2 intron: $386 \mathrm{dTCT}$; six ES in the USP33 intron: 267 $\mathrm{G}=>\mathrm{A}, 279 \mathrm{~T}=>\mathrm{C}, 309 \mathrm{dAA}, 538 \mathrm{G}=>\mathrm{T}, 805 \mathrm{~A}=>\mathrm{G}, 928 \mathrm{G}=>\mathrm{A}$.

\section{Type material examined}

Neotype (here designated)

NAMIBIA - 1 specimen (mounted skeleton), "Giraffe of Levaillant"; North of the Orange river; MNHN-A7977.

\section{Distribution}

Angola, Botswana, Mozambique, Namibia (neotype), South Africa, Zambia, Zimbabwe.

\section{Remarks}

No concrete holotype specimen assigned, as specimens of the Prince of Orange Museum in The Hague and the giraffe of Vosmaer (1787) from the Naturalis museum in Leiden (Netherlands) are 'whereabouts unknown'.

\section{Giraffa giraffa giraffa (Boddaert, 1784)}

Camelopardalis australis Swainson, 1835: 284.

Camelopardalis capensis Lesson, 1842: 168.

Camelopardalis maculata Weinland, 1863: 205, fig. p. 206.

Giraffa camelopardalis angolensis Lydekker, 1903: 121, fig. p. 121.

\section{Diagnosis}

One ES in the Cytb gene: $798 \mathrm{~T}=>\mathrm{C}$; two ES in the CR: $130 \mathrm{iT}, 170 \mathrm{~A}=>\mathrm{G}$.

\section{Distribution}

Angola, Botswana, Namibia, Zimbabwe. 
Giraffa giraffa wardi Lydekker, 1904

Giraffa infumata Noack, 1903: 356.

\section{Diagnosis}

Irregular spots, spots on the side of the face restricted to the region below and behind the eyes, two ES in the Cytb gene: $634 \mathrm{C}=>\mathrm{T}, 705 \mathrm{~A}=>\mathrm{G}$.

\section{Type material}

Holotype

SOUTH AFRICA • 1 specimen (mounted head and neck); NHMUK-1903.11.18.1.

\section{Distribution}

Botswana, Mozambique, South Africa (holotype), Zambia, Zimbabwe.

\section{Remarks}

The holotype is given by Lydekker (1914) under the collection number NHMUK-1903.11.18.1, but this catalogue number leads to a fish specimen (Pomatomus telescopus Risso, 1810) on the collection website (https://data.nhm.ac.uk/dataset/collection-specimens/resource/05ff2255-c38a-40c9-b657$4 \mathrm{ccb} 55 \mathrm{ab} 2 \mathrm{feb} / \mathrm{record} / 3124756$ ). However, two other specimens of wardi can be found in the museum collection (NHMUK-1903.11.17.1 and NHMUK-1903.11.17.3), one of which might be considered the neotype if the holotype cannot be found.

\section{Acknowledgement}

We want to express our gratitude for the provision of samples to Anick Abourachid, Jacques Cuisin, Christine Lefevre, Joséphine Lesur and Eric Pellé in the MNHN in Paris (France), Francis Duranthon, Henri Cap, Fabienne Facy and Arnaud Malabre in the Muséum d'histoire naturelle in Toulouse (France), Emmanuel Gilissen and Jos Snoeks in the Musée royal de l'Afrique centrale in Tervuren (Belgium), Olivier Pauwels in the Institut royal des Sciences naturelles de Belgique in Brussels (Belgium), Christiane Funk and Frieder Mayer of the Museum für Naturkunde in Berlin (Germany), Rob Ogden and the Al Ain Zoo (United Arab Emirates), Alexis Lécu in the Parc zoologique de Paris, Baptiste Mulot and other staff members of the Beauval Zoo (France). We also thank Antoine Maillard for logistical assistance in Kenya, and Anne-Marie Ohler for helpful comments on the first version of the manuscript. The $\mathrm{PhD}$ thesis of AP was funded by LabEx BCDiv (https://labex-bcdiv.mnhn.fr) (project written by AH in 2015). This work was supported by the PPF « Biodiversité actuelle et fossile», ATM Collections Vivantes, and by a grant from Agence Nationale de la Recherche under the LabEx ANR-10-LABX-0003-BCDiv, in the program "Investissements d'avenir" n ANR-11-IDEX-0004-02.

\section{References}

Allin M. 1999. Zarafa: a Giraffe's True Story, from Deep in Africa to the Heart of Paris. Walker and Co., New York.

Ansell W.F.H. 1968. Artiodactyla (Excluding the Genus Gazella). In: Meester J.A. (ed.) Preliminary Identification Manual for African Mammals: 152-160. Smithsonian Institution, Washington.

Baker R.J. \& Bradley R.D. 2006. Speciation in mammals and the genetic species concept. Journal of Mammalogy 87: 643-662. https://doi.org/10.1644/06-MAMM-F-038R2.1

Baker S.W. 1880. Exploration du Haut Nil: récit d'un Voyage dans l'Afrique centrale. Librairie Hachette, Paris. 
Bandelt H.J., Forster P. \& Röhl A. 1999. Median-joining networks for inferring intraspecific phylogenies. Molecular Biology and Evolution 16 (1): 37-48.

https://doi.org/10.1093/oxfordjournals.molbev.a026036

Baum D.A. \& Shaw K.L. 1995. Genealogical perspectives on the species problem. In: Hoch P.C. \& Stephenson A.G. (eds) Experimental and Molecular Approaches to Plant Biosystematics: 289-303. Missouri Botanical Garden, Saint Louis.

Belon du Mans P. 1553. Les Observations de plusieurs Singularitez et Choses memorables trouvees en Grece, Asie, Iudée, Egypte, Arabie et autres Pays estranges. Corrozet et Canellat, Paris.

https://doi.org/10.5962/bhl.title.127374

Bercovitch F.B. \& Berry P.S. 2010. Ecological determinants of herd size in the Thornicroft's giraffe of Zambia. African Journal of Ecology 48 (4): 962-971. https://doi.org/10.1111/j.1365-2028.2009.01198.x

de Blainville H.M.D. 1864. Ostéographie: ou, Description iconographique comparée du Squelette et du Système dentaire des Mammifères récents et fossiles pour servir de base à la Zoologie et à la Géologie. Vol. 4: Quaternatès. JB Baillière et fils, Paris.

Bock F., Fennessy J., Bidon T., Tutchings A., Marais A., Deacon F. \& Janke A. 2014. Mitochondrial sequences reveal a clear separation between Angolan and South African giraffe along a cryptic rift valley. BMC Evolutionary Biology 14 (1): 219. https://doi.org/10.1186/s12862-014-0219-7

Boddaert P. 1784. Camelopardalis giraffa. Elenchus Animalium Vol. 1: Systems Quadrupedia. C.R. Hake, Rotterdam.

Bostock J. \& Riley H.T. 1855. Pliny the Elder: The Natural History. Taylor and Francis, London.

Bouckaert R., Heled J., Kühnert D., Vaughan T., Wu C.H., Xie D., Suchard M.A., Rambaut A. \& Drummond A.J. 2014. BEAST 2: a software platform for Bayesian evolutionary analysis. PLoS Computational Biology 10 (4): e1003537. https://doi.org/10.1371/journal.pcbi.1003537

Brisson M.J. 1762. Regnum Animale in Classes IX.: Distributum, sive Synopsis methocica: Sistens generalem Animalium distributionem in Classes IX, \& duarum primarum Classium, Quadrupedum scilicet \& Cetaceorum, particularem divisionem in Ordines, Sectiones, Genera \& Species. Theodorum Haak, Leiden. https://doi.org/10.5962/bhl.title.40361

Brown D.M., Brenneman R.A., Koepfli K.P., Pollinger J.P., Milá B., Georgiadis N.J., Edward Jr. E.L., Grether G.F., Jacobs D.K. \& Wayne R.K. 2007. Extensive population genetic structure in the giraffe. $B M C$ Biology 5 (1): 57. https://doi.org/10.1186/1741-7007-5-57

Bryden H.A. 1899. Great and Small Game of Africa: An Account of the Distribution, Habits, and Natural History of the Sporting Mammals, with Personal Hunting Experiences. R. Ward, London.

Ciofolo I. \& Le Pendu Y. 2013. Giraffa camelopardalis. In: Kingdon J. \& Hoffman M. (eds) Mammals of Africa. Vol. 6: Pigs, Hippopotamuses, Chevrotain, Giraffes, Deer and Bovids: 98-110. Bloomsbury Publishing, London.

Combes E. \& Tamisier M. 1838. Voyage en Abyssinie, dans les Pays des Galla, de Choa et d'ifat, précédé d'une Excursion dans l'Arabie-Heureuse et accompagné d'une de ces diverses contrées. L. Dessart, Paris.

Dagg A.I. 1962. The subspeciation of the giraffe. Journal of Mammalogy 43 (4): 550-552. https://doi.org/10.2307/1376925

Dagg A.I. 1971. Giraffa camelopardalis. Mammalian Species 5: 1-8. https://doi.org/10.2307/3503830

Dagg A.I. \& Foster J.B. 1976. The Giraffe: its Biology, Behaviour, and Ecology. Van Nostrand Reinhold Company, New York. 
Dagg A.I. 2014. Giraffe: Biology, Behaviour and Conservation. Cambridge University Press, Cambridge.

Darriba D., Taboada G.L., Doallo R. \& Posada D. 2012. jModelTest 2: more models, new heuristics and parallel computing. Nature methods 9 (8): 772-772. https://doi.org/10.1038/nmeth.2109

Delalande P.A. 1822. Précis d'un Voyage au cap de Bonne-Esperance : fait par ordre du Gouvernement. A. Belin, Paris.

Donoghue M.J. 1985. A critique of the biological species concept and recommendations for a phylogenetic alternative. Bryologist 1985: 172-181.

Drummond A.J., Suchard M.A., Xie D. \& Rambaut A. 2012. Bayesian phylogenetics with BEAUti and the BEAST 1.7. Molecular Biology and Evolution 29 (8): 1969-1973.

https://doi.org/10.1093/molbev/mss075

Duvernoy M. 1844. Sur une mâchoire de girafe fossile découverte à Issoudun. Notes communiqués au L'Academie de Science, 1843.

East R. 1998. African Antelope Database. IUCN/SSC Antelope Specialist Group, Gland. Available from https://portals.iucn.org/library/efiles/documents/ssc-op-021.pdf [accessed 27 Jul. 2020].

Fennessy J. \& Marais A. 2018. Giraffa camelopardalis ssp. antiquorum. The IUCN Red List of Threatened Species 2018: e.T88420742A88420817.

https://doi.org/10.2305/IUCN.UK.2018-2.RLTS.T88420742A88420817.en

Fennessy J., Bock F., Tutchings A., Brenneman R. \& Janke A. 2013. Mitochondrial DNA analyses show that Zambia's South Luangwa Valley giraffe (Giraffa camelopardalis thornicrofti) are genetically isolated. African Journal of Ecology 51 (4): 635-640. https://doi.org/10.1111/aje.12085

Fennessy J., Bidon T., Reuss F., Kumar V., Elkan P., Nilsson M. A., Vamberger M., Fritz U. \& Janke A. 2016. Multi-locus analyses reveal four giraffe species instead of one. Current Biology 26 (18): 25432549. https://doi.org/10.1016/j.cub.2016.07.036

Fennessy J., Marais A., \& Tutchings A. 2018. Giraffa camelopardalis ssp. peralta. The IUCN Red List of Threatened Species 2018: e.T136913A51140803.

https://doi.org/10.2305/IUCN.UK.2018-2.RLTS.T136913A51140803.en

Geoffroy Saint-Hilaire É. 1827. Quelques considérations sur la giraffe. Annales des Sciences naturelles 11: 210-223.

Goudie A.S. 2005. The drainage of Africa since the Cretaceous. Geomorphology 67 (3-4): 437-456. https://doi.org/10.1016/j.geomorph.2004.11.008

Guindon S., Dufayard J.F., Lefort V., Anisimova M., Hordijk W. \& Gascuel O. 2010. New algorithms and methods to estimate maximum-likelihood phylogenies: assessing the performance of PhyML 3.0. Systematic Biology 59 (3): 307-321. https://doi.org/10.1093/sysbio/syq010

Happold D.C.D. 1969. The present distribution and status of the giraffe in West Africa. Mammalia 33 (3): 516-521. https://doi.org/10.1515/mamm.1969.33.3.516

Happold D.C.D. 1978. Giraffe south of the Niger-Benue River system. Zeitschrift für Sängetierkunde 43 (4): 239-242.

Harris J.M. 1991. The Fossil Ungulates: Geology, Fossil Artiodactyls, and Palaeoenvironments. Clarendon Press, Oxford. 
Hassanin A., Ropiquet A., Gourmand A.L., Chardonnet B. \& Rigoulet J. 2007. Mitochondrial DNA variability in Giraffa camelopardalis: consequences for taxonomy, phylogeography and conservation of giraffes in West and central Africa. Comptes Rendus Biologies 330 (3): 265-274.

https://doi.org/10.1016/j.crvi.2007.02.008

Hassanin A., Delsuc F., Ropiquet A., Hammer C., Van Vuuren B.J., Matthee C., Ruiz-Garcia M., Catzeflis F., Areskoug V., Nguyen T.T. \& Couloux A. 2012. Pattern and timing of diversification of Cetartiodactyla (Mammalia, Laurasiatheria), as revealed by a comprehensive analysis of mitochondrial genomes. Comptes Rendus Biologies 335 (1): 32-50. https://doi.org/10.1016/j.crvi.2011.11.002

Hasselquist F. 1757. Iter Palaestinum eller Resa til Heliga Landet forrattad ifran ar 1749 til 1752. Laurentius Salvius, Stockholm. https://doi.org/10.5962/bhl.title.112563

Henderson D.M. \& Naish D. 2010. Predicting the buoyancy, equilibrium and potential swimming ability of giraffes by computational analysis. Journal of Theoretical Biology 265 (2): 151-159.

https://doi.org/10.1016/j.jtbi.2010.04.007

Jardine W. 1835. The Natural History of the Ruminating Animals, containing Deer, Antilopes, Camels \& c. W. H. Lizars, Edinburgh. https://doi.org/10.5962/bhl.title.131528

Johnson T.C., Kelts K. \& Odada E. 2000. The Holocene history of Lake Victoria. Ambio 29 (1): 2-11. https://doi.org/10.1579/0044-7447-29.1.2

Joly N. \& Lavocat A. 1845. Recherches historiques, zoologiques, anatomiques et paléontologiques sur la Giraffe (Camelopardalis giraffa, Gmélin). V. Berger-Levrault, Boulogne-Billancourt.

Kingdon J. 1997. The Kingdon Field Guide to African Mammals. Academic Press, London.

Knottnerus-Meyer T. 1910. Eine neue Giraffe aus dem südlichen Abessinien. Zoologischer Anzeiger 35: 797-800.

Leigh J.W. \& Bryant D. 2015. PopArt: full-feature software for haplotype network construction. Methods in Ecology and Evolution 6 (9): 1110-1116. https://doi.org/10.1111/2041-210X.12410

Lesson R.P. 1842. Nouveau tableau du Règne animal: Mammifères. Arthus Bertrand, Paris.

Levaillant F. \& de La Borde J.-B. 1790. Partie Méridionale de l'A frique depuis le Tropique du Capricorne jusqu'au Cap de Bonne Espérance contenant les Pays des Hottentots, des Cafres et de quelques autres Nations. Available from https://gallica.bnf.fr/ark:/12148/btv1b55011014j/f2.item.r=Levaillant\%20 carte\%20meridionale\%20de\%201'afrique\%20Levaillant [accessed 24 Jul. 2020].

Levaillant F. 1797. Second Voyage dans l'Intérieur de l'Afrique par le Cap de Bonne-Espérance, dans les années 1783-1785 (Vol. 2). B. Le Francq, Bruxelles. https://doi.org/10.5962/bhl.title.125944

Linnaeus C. 1758. Systema Naturae per Regna Tria Naturae. Editio decima reformata, Tomus I. Regnum Animale. Laurentius Salvius, Stockholm.

Lydekker R. 1903. Local variation in the Giraffe. In: Animal Life and the World of Nature. Vol. 2: 78-84. Hutchinson \& Co, London.

Lydekker R. 1904. On the Subspecies of Giraffa camelopardalis. Proceedings of the Zoological Society of London 74: 202-227. https://doi.org/10.1111/j.1469-7998.1904.tb08288.x

Lydekker R. 1911. Two undescribed giraffes. Nature 87: 484. https://doi.org/10.1038/087484c0

Lydekker R. 1914. Catalogue of the Ungulate Mammals in the British Museum. British Museum, London.

MacClintock D. 1973. A Natural History of Giraffes. Charles Scribner's Sons, New York.

Malte-Brun C. \& Malte-Brun V.A. 1839. Nouvelles Annales des Voyages. A. Pihan de la Forest, Paris. 
Matschie P. 1898. Einige anscheinend noch nicht beschriebene Säugetiere aus Afrika. Sitzungsbericht Gesellschaft Naturforschender Freunde zu Berlin 1898: 75-81.

McCorquodale W.H. 1898. Giraffe from the Niger Territories. Nature 57: 389-390.

https://doi.org/10.1038/057389c0

de Menocal P.B. 2004. African climate change and faunal evolution during the Pliocene-Pleistocene. Earth and Planetary Science Letters 220 (1-2): 3-24. https://doi.org/10.1016/S0012-821X(04)00003-2

Moore A.E., Cotterill F.P.D. \& Eckardt F.D. 2012. The evolution and ages of Makgadikgadi palaeolakes: consilient evidence from Kalahari drainage evolution south-central Africa. South African Journal of Geology 115 (3): 385-413. https://doi.org/10.2113/gssajg.115.3.385

Muller Z., Bercovitch F., Brand R., Brown D., Brown M., Bolger D., Carter K., Deacon F., Doherty J.B., Fennessy J., Fennessy S., Hussein A.A., Lee D., Marais A., Strauss M., Tutchings A. \& Wube T. 2018. Giraffa camelopardalis (amended version of 2016 assessment). The IUCN Red List of Threatened Species 2018: e.T9194A136266699. https://doi.org/10.2305/IUCN.UK.2016-3.RLTS.T9194A136266699.en

Nežerková P., Verner P.H. \& Antonínová M. 2004. The conservation programme of the western giant eland (Taurotragus derbianus derbianus) in Senegal-Czech Aid Development Project. Gazella 31: 87182.

Noack T. 1908. Die Giraffe des Sambesi-Gebietes. Zoologischer Anzeiger 33 (11): 354-356.

Ogilby W. 1837. On the generic characters of ruminants. Proceedings of the Zoological Society of London 1836: 131-139.

Petzold A. \& Hassanin A. 2020. A comparative approach for species delimitation based on multiple methods of multi-locus DNA sequence analysis: A case study of the genus Giraffa (Mammalia, Cetartiodactyla). PloS ONE 15 (2): e0217956. https://doi.org/10.1371/journal.pone.0217956

Rambaut A. \& Drummond A.J. 2007. TreeAnnotator. Program and documentation distributed by the author. Available from http://beast.bio.ed.ac.uk/TreeAnnotator [accessed 25 Jul. 2020].

Rambaut A., Drummond A.J., Xie D., Baele G. \& Suchard M.A. 2018. Posterior summarization in Bayesian phylogenetics using Tracer 1.7. Systematic Biology 67 (5): 901-904.

https://doi.org/10.1093/sysbio/syy032

Ray J. 1693. Synopsis Methodica Animalium quadrupedum et serpentini Generis. Smith \& Walford, London.

Rhoads S.N. 1896. Mammals collected by Dr. A. Donaldson Smith during his expedition to Lake Rudolf, Africa. Proceedings of the Academy of Natural Sciences of Philadelphia 1896: 517-546.

Rigoulet J. 2012. Histoire de Zarafa, la girafe de Charles X. Bulletin de l'Académie vétérinaire de France 165: 169-176. https://doi.org/10.4267/2042/48205

Roeder P., Mariner J. \& Kock R. 2013. Rinderpest: the veterinary perspective on eradication. Philosophical Transactions of the Royal Society B: Biological Sciences 368 (1623): 20120139.

https://doi.org/10.1098/rstb.2012.0139

Rohland N. \& Hofreiter M. 2007. Ancient DNA extraction from bones and teeth. Nature Protocols 2 (7): 1756-1762. https://doi.org/10.1038/nprot.2007.247

Ronquist F., Teslenko M., Van Der Mark P., Ayres D.L., Darling A., Höhna S., Larget B., Liu L., Suchard M.A. \& Huelsenbeck J.P. 2012. MrBayes 3.2: efficient Bayesian phylogenetic inference and model choice across a large model space. Systematic Biology 61 (3): 539-542.

https://doi.org/10.1093/sysbio/sys029 
PETZOLD A. et al., Past biodiversity of giraffes

Rüppell E. 1826. Atlas zu der Reise im nördlichen Afrika. HL Brönner, Frankfurt am Main. https://doi.org/10.5962/bhl.title.53779

Salze Mr. 1827. Observations faites sur la Girafe envoyée au Roi par le Pacha d'Égypte. Mémoires du Muséum d'histoire naturelle 14: 68-84.

von Schreber J.C.D. 1784. Die Säugthiere in Abbildungen nach der Natur mit Beschreibungen. Palm'sche Verlagsbuchhandlung, Erlangen.

Schickh J. 1828. Wiener-Moden-Zeitung und Zeitschrift für Kunst, schöne Literatur und Theater. Anton Strauß sel. Witwe, Wien.

Shorrocks B. 2016. The Giraffe: Biology, Ecology, Evolution and Behaviour. John Wiley \& Sons, New Jersey. https://doi.org/10.1002/9781118587430

Sidney J. 1965. The past and present distribution of some African ungulates. Transactions of the Zoological Society of London 30: 139-168.

Stott K.W. \& Selsor C.J. 1981. Further remarks on giraffe intergradation in Kenya and unreported marking variations in reticulated and Masai giraffes. Mammalia 45: 261-263.

Swainson W. 1835. A Treatise on the Geography and Classification of Animals. Green Longman, London. https://doi.org/10.5962/bhl.title.25975

Swofford D.L. 2002. PAUP* Phylogenetic Analysis Using Parsimony (*And Other Methods). ver. 4.0b10. Sinauer Associates, Sunderland.

Thomas O. 1898. On a new subspecies of giraffe from Nigeria. Proceedings Zoological Society London 1898: 39-41.

Trouessart L. 1898. Catalogus Mammalium tam viventium quam fossilium. Vol. 4: Tillodontia et Ungulata. Freidlander, Berlin. https://doi.org/10.5962/bhl.title.130824

Vincke X., Hornick J.L., Njikam N.I. \& Leroy P. 2005. Gestion de la faune sauvage au Sénégal: comparaison du Parc national du Niokolo Koba et de la Réserve privée de Bandia. Annales de Médecine vétérinaire 149 (4): 232-237.

Vosmaer A. 1787. Description du chameau-leopard (Camelopardalis). P. Meyer and G. Warners, Amsterdam.

Weinland D.F. 1863. Zur Erinnerung an unsere Giraffe. Zoologischer Garten 4: 204-207.

Williams M.A., Adamson D., Prescott J.R. \& Williams F.M. 2003. New light on the age of the White Nile. Geology 31 (11): 1001-1004. https://doi.org/10.1130/G19801.1

Wilson D.E. \& Mittermeier R.A. 2011. Handbook of the Mammals of the World. Vol. 2: Hoofed Mammals. Lynx Edicions, Barcelona.

Winter S., Fennessy J., Fennessy S. \& Janke A. 2018a. Matrilineal population structure and distribution of the Angolan giraffe in the Namib desert and beyond. Ecological Genetics and Genomics 7: 1-5.

https://doi.org/10.1016/j.egg.2018.03.003

Winter S., Fennessy J. \& Janke A. 2018b. Limited introgression supports division of giraffe into four species. Ecology and Evolution 8 (20): 10156-10165. https://doi.org/10.1002/ece3.4490

de Winton W.D. 1899. On the giraffe of Somaliland (Giraffa camelopardalis reticulata). Annals and Magazine of Natural History 7 (4): 211-212. https://doi.org/10.1080/00222939908678186

Wube T., Doherty J.B., Fennessy J. \& Marais A. 2018. Giraffa camelopardalis ssp. camelopardalis. The IUCN Red List of Threatened Species 2018: e.T88420707A88420710.

https://doi.org/10.2305/IUCN.UK.2018-2.RLTS.T88420707A88420710.en. 
Yin Q.Z. \& Guo Z.T. 2007. Strong summer monsoon during the cool MIS-13. Climate of the Past Discussions 3: 1119-1132. https://doi.org/10.5194/cpd-3-1119-2007

Zabeirou R. 2017. National Survey Report of the West African Giraffe, Niger - August 2017. Giraffe Conservation Foundation and Sahara Conservation Fund, Niamey, Niger.

Manuscript received: 13 March 2020

Manuscript accepted: 3 July 2020

Published on: 18 August 2020

Topic editor: Koen Martens

Desk editor: Radka Rosenbaumová

Printed versions of all papers are also deposited in the libraries of the institutes that are members of the EJT consortium: Muséum national d'histoire naturelle, Paris, France; Meise Botanic Garden, Belgium; Royal Museum for Central Africa, Tervuren, Belgium; Royal Belgian Institute of Natural Sciences, Brussels, Belgium; Natural History Museum of Denmark, Copenhagen, Denmark; Naturalis Biodiversity Center, Leiden, the Netherlands; Museo Nacional de Ciencias Naturales-CSIC, Madrid, Spain; Real Jardín Botánico de Madrid CSIC, Spain; Zoological Research Museum Alexander Koenig, Bonn, Germany; National Museum, Prague, Czech Republic. 


\section{Supplementary material}

Supplementary file 1 List of 22 newly generated sequences for giraffes from current populations.

Supplementary file 2 List of primer combinations used for the amplification of historical DNA.

Supplementary file 3 Individual code, designation of subspecies and origin of the 75 giraffe samples sequenced for mitochondrial and nuclear markers.

Supplementary file 4 Bayesian tree from the analysis of the mtDNA-91T dataset.

Supplementary file 5 PhyML tree from the Maximum Likelihood analysis of the mtDNA-91T dataset.

Supplementary file 6 Bayesian tree from the analysis of the nuDNA-78T dataset.

Supplementary file 7 PhyML tree from the Maximum Likelihood analysis of the nuDNA-78T dataset.

Supplementary file 8 Comparison of mitochondrial and nuclear divergence time estimates.

Supplementary file 9 Exclusive synapomorphies characterizing giraffe taxa in the mtDNA-91T dataset.

Supplementary file 10 Exclusive synapomorphies characterizing giraffe taxa in the nuDNA-78T dataset. 